\title{
ARTICLES \\ THE ORIGINALIST MYTH OF THE UNITARY EXECUTIVE
}

\author{
Peter M. Shane
}

\begin{abstract}
Both Executive Power Vesting Clauses and clauses equivalent to Article II's Faithful Execution Clause were prevalent in early state constitutions that nonetheless fractured gubernatorial control over state bureaucracies. Originalist defenders of a unitary executive reading of the federal Constitution nonetheless dismiss the interpretive significance of the pre-1787 state constitutions. These early texts supposedly paid only lip service to separation of powers principles, while presenting the Framers chiefly with examples of government structure to avoid. The core problem with this originalist stance is that state constitutions written in the first decades after 1789 persisted in using the same clauses, now found also in Article II, to describe state governments in which governors continued to lack unitary control. Close study of the state constitutions and state administrative practice under them thus belie any "unitary executive" reading of Article II that purports to be based on "original public meaning." These findings are also consistent with the early history of federal public administration, which corroborates a common understanding that Article II's vesting of executive power permitted substantial legislative control over the allocation of decisional authority within the executive branch.
\end{abstract}

\section{TABLE OF CONTENTS}

INTRODUCTION. 324

I. VARIETIES OF ORIGINALISM 330

\section{Public Meaning Originalism ANd the Early State} CONSTITUTIONS

* Jacob E. Davis and Jacob E. Davis II Chair in Law, Ohio State University Moritz College of Law. Portions of this Article will appear in a Cambridge University Press volume honoring Professor Jerry Mashaw on the occasion of his alleged retirement, Peter M. Shane, Boundary Disputes: Jerry Mashaw's Anti-Formalism, Constitutional Interpretation and the Unitary Executive, in AMERICAN ADMINISTRATIVE LAW FROM THE INSIDE OUT: EsSAYS ON THEMES IN THE WORK OF JERRY MASHAW (Nicholas Parrillo ed., 2016). I am grateful for the outstanding research assistance of Moritz College of Law reference librarian Paul J. Gatz and Benjamin F.C. Wallace, M.A., J.D. '16, in preparing this Article, as well as for the comments on earlier drafts from Richard Fallon, Jeffrey Sutton, Christopher Walker, and participants in the Oct. 2-3, 2015 Yale Law School Symposium, "Administrative Law from the Inside Out: A Conference on Themes in the Work of Jerry Mashaw." I am also deeply thankful for comments from Professor Saikrishna Prakash, whose work I undertake, in part, to critique. Professor Prakash and I are well into our second decade of collegial debate on the scope of executive power, and his generosity in helping me to sharpen arguments with which he no doubt continues to disagree has been a wonderful gift. 


\section{AdMinistrative Practice Under the EARLy State} CONSTITUTIONS

IV. Old ORIGINALISM: ThE CASE OF THE NATIONAL BANK .........352

CONCLUSION. 360

\section{APPENDIX: STATE LEVEL ADMINISTRATIVE OFFICIALS IN EARLY STATE CONSTITUTIONS......} 363

\section{INTRODUCTION}

Debates about the President's constitutional relationship to the federal bureaucracy are as old as the Republic and show little sign of abating. Proponents of what I would call the "hard version" of the unitary executive thesis interpret the Constitution as guaranteeing the President plenary authorities, which Congress may not limit, both to discharge unelected executive administrators at will and to direct how they shall exercise any and all discretionary authority that those officials possess under law. ${ }^{1}$ Dissenters, of whom I am one, agree that the President enjoys such control over subordinate personnel who assist the President in performing specific constitutionally enumerated tasks, such as negotiating treaties or commanding the military. We believe, however, that the scope of the President's removal and directive powers with respect to most administrators is subject to congressional regulation. ${ }^{2}$ In this more pluralist reading of the

1 See generally STEVEN G. CALABRESI \& CHRISTOPHER S. YOO, THE UNITARY EXECUTIVE: PRESIDENTIAL POWER FROM WASHINGTON TO BUSH (2008) (describing the omnipotency of the American presidency and why the other branches of government are subservient to it).

2 See generally Peter M. SHAne, Madison's Nightmare: How Executive Power Threatens AMERICAN DEMOCRACY (2009) (explicating how the executive branch is limited by the other two branches and why such limitations are an important facet of democracy). Within what I would call this latter checks-and-balances camp, scholars further divide on how to read administrative statutes. Some argue that, in the face of statutory silence, we should presume that Congress intends the President to have both complete removal and directive powers. See generally Elena Kagan, Presidential Administration, 114 HARV. L. REv. 2245 (2001) (delineating two ways to interpret an organic statute's silence on delegation: assuming it runs from Congress only to the agency official, or assuming that delegation is still subject to the ultimate control of the President). This might be called the "soft unitary executive" thesis. Others argue-again, I am in this group-that, even if a removal power is presumed (a presumption that may be overcome by the nature of the official's particular tasks per Wiener v. United States, 357 U.S. 349 (1958)), a directive power should not be. See Kevin M. Stack, The President's Statutory Powers to Administer the Laws, 106 Colum. L. ReV. 263, 277 (2006) (arguing that the President has statutory 
Constitution, a President may have authority to persuade an official to exercise her lawful administrative discretion in ways the President favors; if the administrator demurs, however, the President has to live with the disagreement unless the administrator is legally subject to policy-based removal and the President is willing to remove that official.

With few exceptions, proponents of a hard unitary executive defend their reading of the Constitution on purportedly originalist grounds. It has been argued, for example, from a variety of historical sources that the hard version of the unitary executive is what the Framers or ratifiers intended and that we are bound by their intentions. The primary-in my judgment, fatal-problem with the argument from original intent is that early administrative practice was often at odds with this vision of the presidency. As Jerry Mashaw has written, the First Congress "seems to have had no fixed general idea about the relationship of the President to administration." "3 It is odd to think that our earliest legislators, many of whom helped to draft the Constitution, were either unaware of original intentions or indifferent to them.

A somewhat different strategy of originalist interpretation, however, relies less on a search for intent per se and more on what "new originalists" call the "original public meaning" of the Article II text. ${ }^{4}$ Under this approach, what would make the hard version of the unitary executive binding is not what Framers or ratifiers might subjectively have had in mind, but rather what a contemporary educated reader of the Article II text would

authority to direct administration of laws under statutes only when that statute grants power to the President in name); Peter L. Strauss, Overseer, or "The Decider"? The President in Administrative Law, 75 GEO. WASH. L. REV. 696 (2007) (questioning whether Congress's grant of authority to the President confers the ability to made administrative decisions or simply oversee agency decision processes).

3 See Jerry L. Mashaw, Governmental Practice and Presidential Direction: Lessons from the Antebellum Republic?, 45 WiLlametTE L. REV. 659, 668 (2009) (arguing that based on early government administrative statutes, it is clear that Congress did not have a singular definition of the roles of the President and administrative agencies).

4 For example, it was on the basis of its understanding of "original public meaning" that the U.S. Court of Appeals for the District of Columbia Circuit would have held that the President's recess appointments power may be exercised only during the Senate's intersession recesses and only to fill vacancies first arising during those recesses. Noel Canning v. N.L.R.B., 705 F.3d 490, 505 (D.C. Cir. 2013), aff'd on other grounds, 134 S. Ct. 2550 (2014) ("In context, 'the Recess' refers to a specific state of the legislature, so sources other than general dictionaries are more helpful in elucidating the term's original public meaning."). Although affirming the Court of Appeals on a different ground-namely, the brevity of the period of adjournment at issue-the Supreme Court rejected the Court of Appeals interpretation on both these points. The Court concluded that the Recess Appointments Clause was too ambiguous to yield a persuasive originalist interpretation. N.L.R.B. v. Noel Canning, 134 S. Ct. 2550, 2561 (2014) ("The constitutional text is ... ambiguous. And we believe the Clause's purpose demands [a] broader interpretation."). 
have taken it to prescribe. The hard version of the unitary executive, in this view, follows from the original public meaning of the Article II declaration that " $[t]$ he executive power shall be vested in a President of the United States of America," read either in isolation or as contextualized by other key clauses of Article II. This reading is rooted in a syllogism: "Executive power," in the late eighteenth century, meant "not legislative" and "having the power to put in act the laws." Vesting "the" executive power meant vesting all of executive power as a singular, indivisible authority. Vesting that authority in "a" President meant that it would be shared by no other individual.

In 2003, Professor Saikrishna Prakash provided a thoughtful and learned defense of this reading, purporting to show how the textualist syllogism makes sense of other portions of Article II and is corroborated by more contextual evidence from eighteenth century political theory, debates in Philadelphia and during the ratification period, and statements by George Washington, Alexander Hamilton, James Madison, and Justice James Wilson following the founding. ${ }^{6}$ His historical exploration leads him to conclude that the federal Article II Executive Power Clause not only allows presidents to direct those inferior officers charged with carrying out the law, but actually authorizes the federal Chief Executive to "execute any federal law by himself." His position would go a long way toward establishing a hard

5 Saikrishna Prakash, The Essential Meaning of Executive Power, 2003 U. ILL. L. ReV. 701, 716 (2003) [hereinafter Prakash, The Essential Meaning of Executive Power] (quoting 1 SAMUEL Johnson, A Dictionary of the English Language 684 (4th ed. 1773)). Professor Prakash has further elaborated upon his views in SAIKRISHNA BANGALORE PraKasH, IMPERIAL FROM THE BEgINNING: THE CONSTITUTION OF THE ORIGINAL EXECUTIVE 1-11 (2015) [hereinafter Prakash, THE CONSTITUtion OF THE ORIGINAL Executive] (defending the plausibility of discerning a clear conception of the Article II presidency by analyzing eighteenth century usage).

6 See Prakash, The Essential Meaning of Executive Power, supra note 5, at 713-42 (exploring the textual foundations for the chief executive thesis). His newer work argues that late eighteenth century usage substantiates a widespread understanding that federal "executive power" referred to the "execution of federal law, management of foreign affairs, and direction of executive officers." Prakash, THE CONSTITUTION OF THE ORIGINAL EXECUTIVE, supra note 5, at 63, 80. He also offers a somewhat different formulation-a "bundle of powers—over law execution, foreign affairs, and the military." $I d$. at 68. At a high level of generality, I do not disagree and even endorse Professor Prakash's general position that the Executive Power Vesting Clause is properly understood as implying some grants of power beyond the precise terms of the rest of Article II. But, as Professor Prakash acknowledges, "[T]here were disagreements [in eighteenth century America] about the scope of executive power." Id. at 66. Where Professor Prakash and I differ is in our views as to which aspects of executive power fell within "widespread understanding" and which aspects were subjects of "disagreement," or simply not well-conceptualized at the time.

7 Prakash, The Essential Meaning of Executive Power, supra note 5, at 704. In two respects, the article does not purport to be a full-throttle textualist defense of unitary executive theory. First, Professor Prakash does not attempt to "fully explicate what is meant by presidential 
version of the unitary executive; it would recognize a presidential power to make every act of the federal executive establishment quite literally his own.

Although Professor Prakash's work repays close reading, it remains unpersuasive for two main reasons. The first, which I will not dwell on at any length, is that early attorneys general with very different political ideologies seem to have taken the precisely opposite view on the very point Professor Prakash stresses:

Attorneys General [William] Wirt and [Roger] Taney were ideological opposites concerning the true institutional seat of democracy in the United States. Wirt placed it in Congress; Taney in the President. But, both agreed that the President could not substitute his judgment for an officer charged by statute with a particular function. ${ }^{8}$

control of law execution," $i d$. at 705 , thus perhaps leaving some ambiguity concerning the scope of presidential entitlement with regard to controlling subordinate officers. Second, in the 2003 article he does not deal with the scope of the President's removal power, $i d$. at 704-05, often regarded as another essential attribute of the "unitary executive." As Professor Prakash's other work makes clear, however, his position on presidential removal is complex and perhaps unique. He does not think Congress is constitutionally entitled to create the "quasi-judicial" or "quasi-legislative" offices that control the so-called independent agencies. See Steven G. Calabresi \& Saikrishna B. Prakash, The President's Power to Execute the Laws, 104 YALE L.J. 541, 567-68 (1994) (arguing that non-executive administrations do not exist because "no independent federal administrative officers were ever contemplated by the Framers"). But he argues that-to the extent Congress does create such offices- the President's Article II removal powers do not extend to them. See Saikrishna Prakash, Removal and Tenure in Office, 92 VA. L. REv. 1779, 1784 (2006) (“[T] he Constitution does not grant [the President] the authority to remove the quasi-judicial and quasi-legislative officers who control the independent agencies. If the President's removal power arises from the grant of executive power, the President has far less removal authority than is commonly supposed."). If I understand this correctly, the Prakash view of Article II would give the President authority to exercise personally all law execution powers vested in any officer within the administrative bureaucracy, but power to remove only those officers who were doing entirely "executive" work. For its part, the Supreme Court has disavowed the utility of such formal labels for delimiting the scope of the President's removal powers. See Morrison v. Olson, 487 U.S. 654, 689 (1988) ("[O]ur present considered view is that the determination of whether the Constitution allows Congress to impose a 'good cause'-type restriction on the President's power to remove an official cannot be made to turn on whether or not that official is classified as "purely executive."”).

8 Mashaw, supra note 3, at 696. For Wirt's views, see The President and Accounting Officers, 1 Op. Att'y Gen. 624 (1823) (opining that recourse from the settlement of public accounts should be taken to the judiciary or Congress, not the executive department of the government); The President and the Comptroller, 1 Op. Att'y Gen. 636 (1823) (refusing the President the power to intervene in the settlement of accounts before the Comptroller); The President and Accounting Officers, 1 Op. Att'y Gen. 678 (1824) (prohibiting the President from interfering with the settlement of accounts of army contractors); The President and Accounting Officers, 1 Op. Att'y Gen. 705 (1825) ("The President cannot legally interfere with duties belonging to the accounting officers."); The President and Accounting Officers, 1 Op. Att'y Gen. 706 (1825) (The President cannot legally interfere with the accounting officers whilst in the discharge of their duties."). For Taney's views, see Jewels of the Princess Orange, 2 Op. Att'y Gen. 482, 485-89 (1831) 
Indeed, based upon his own extensive research into the first century of federal public administration, Jerry Mashaw regards as one of the few points "settled" in the early decades a rule that presidents lack authority "to exercise personally the statutory jurisdiction of an officer empowered by Congress to make a particular decision or to take a particular action. ${ }^{9}$

(recommending the President order the district attorney to cease prosecution and return the stolen jewels to the minister of the King of the Netherlands); Accounts and Accounting Officers, 2 Op. Att'y Gen. 507-08 (1832) (holding that the President does not have "the power to enter into the correctness of the account" for the purpose of fixing an accounting officer's error). In his 2015 book, Professor Prakash argues that

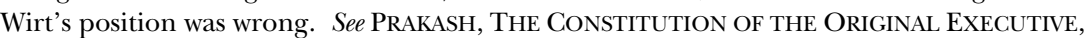
supra note 5, at 190. I presume he would also take this position (i.e., that Wirt was mistaken in his belief that the comptroller and his accountants were bound to have latitude in practice) with regard to Taney. He does note, however, that Wirt's view actually echoes precisely the same position taken by President Jefferson in correspondence addressing the issue. See Letter from Thomas Jefferson to Benjamin Latrobe (June 2, 1808), in ThOMAS JEFFERSON AND THE NATIONAL CAPITAL 429, 431 (Saul K. Padover ed., 1946) (illustrating President Jefferson's unwillingness to interfere with the settlement of accounts with the Treasury as this was the legal job of the Comptroller).

9 See Mashaw, supra note 3, at 695. In support of a contrary view, Professor Prakash's 2015 book mentions an incident during which President Washington appeared personally to exercise all the legal powers vested in his cabinet secretaries because none was physically present to do so. Prakash, The Constitution of the Original EXeCutive, supra note 5 , at 98 . The actual story, however, may support only a more limited claim. The cabinet officers were apparently out of Philadelphia because of the raging Yellow Fever epidemic of 1793. From Mount Vernon, President Washington wrote to his Secretary of War, Henry Knox: "The heads of Departments being absent the disputes arising between the agents of the Powers at War, and other matters, are transmitted immediately to me." Letter from George Washington to Henry Knox (Oct. 15, 1793), http://founders.archives.gov/documents/Washington/05-14-02-0151. It is not clear what "other matters" encompassed. However, the President's personal resolution of disputes between agents of France and England, who were then at war, would seem quite directly to implicate his foreign affairs powers-and might thus have had little relevance to his supervision of ordinary domestic administration. Likewise, the epidemic posed so extraordinary a challenge to administration that the President might have thought himself constitutionally bound as Congress's faithful agent to go beyond the literal terms of statutes vesting authority in particular officers in order to achieve the larger purposes of those statutes. A somewhat expansive view of his role as Congress's agent would also make sense of a 1796 episode in which President Washington, in violation of a statute's precise command, continued to direct the construction of ships even after the United States made peace with Algiers, so that Congress would be able to reconsider the impact of ending construction abruptly. See Prakash, The Constitution of the Original EXECUTIVE, supra note 5, at 94 (recounting President Washington's construction of warships despite statutory commands to stop construction). It was on just such an implied agency theory that the Supreme Court many years later approved President William Taft's technical violation of a statute in order to give Congress time to reconsider the potential impact of literal compliance. For an explanation of this theory, see United States v. Midwest Oil Co., 236 U.S. 459, 475 (1915) (finding that, as an agent of Congress, the Executive was in charge of the public domain).

Nor is it instructive that President Washington personally directed the militia in enforcing federal law. The authority for those actions presumably derived neither from the Executive Power Vesting Clause, nor from his general faithful execution obligation. 
The second point, which this Article is the first to describe in detail, is that similar executive power clauses were also deployed in state constitutions before and after 1787 , but the texts of those constitutions and state practice pursuant to them reveal no agreement at all with the hard version of unitary executive theory. To his credit, Professor Prakash takes due note of the pre1787 constitutions. But he dismisses their textual implications because, "though all chief executives were vested with the 'executive power' or the equivalent, in many states the executive power was exercised at the sufferance of the legislature." ${ }^{10}$ Consequently, Professor Prakash argues, as a matter of federal Framer intent, "state executives were not the templates for the federal chief executive. Rather, most state executives stood as reminders of what to avoid." 11

What is missing, however, from Professor Prakash's reading of the texts is recognition that post-1787 state constitutions took essentially the same textual approach to structuring the executive branch as did the pre-1787 constitutions and federal Article II. In other words, for a textualist to dismiss as Professor Prakash does the evidence of the early state constitutions, she would have to argue two distinct propositions. First, the 1787 readers of the draft federal Article II would have read the federal text as signifying differently from the same words as used in the pre-1787 state constitutions. Second, readers of the post-1787 state constitutions, which duplicated the now-ratified language of federal Article II, would have understood the identical clauses of the new state constitutions to operate more as they had in state constitutions prior to 1787 than they would be expected to operate under the federal Article II. It would take a highly counterintuitive theory of communication to support such a convoluted hypothesis.

Because arguments for the hard version of the unitary executive are almost always originalist, Part I of this Article explains in somewhat more detail the premises of originalism in its formalist versions-both "original intent" and its textualist cousin, "original public meaning." Part II presents the evidence from the texts of state constitutions roughly contemporaneous with the U.S. Constitution. Part III examines state administrative practice pursuant to the early constitutions to confirm that state legislatures acted pursuant to the more relaxed idea of executive control than unitarians have

Rather, Congress, pursuant to Article I, $\S 8$, had authorized calling state militia into federal service for enforcing federal law, and President Washington, having triggered his statutory authority, then acted pursuant to his explicit authority to act as "Commander in Chief of ... the Militia of the several States, when called into the actual Service of the United States." U.S. CONST. art. II, § 2; see also Prakash, The Constitution OF THE ORIGINAL EXECUTIVE, supra note 5, at 98 (describing President Washington's extensive involvement in administrative matters).

10 Prakash, The Essential Meaning of Executive Power, supra note 5, at 760.

$11 \quad$ Id. at 763 . 
recognized. Part IV then shows how this pervasive understanding of the fairly limited implications of executive power vesting clauses makes early federal administrative practice much less surprising. The concluding section explains why the syllogistic reading of Article II's Executive Power Clause does not belie the historical evidence, and urges that a persuasive settlement of the unitary executive debate requires a nonoriginalist exercise in constitutional construction. It suggests the practical factors on which such a construction of the Constitution ought to rely.

\section{VARIETIES OF ORIGINALISM}

Originalism is a variety of constitutional interpretation that comes in different flavors, some of which-if plausible-would be far more constraining on interpretive judgment than others. After all, everyone interpreting the Constitution is, in some sense, an originalist. Constitutional arguments are invariably tethered to some textual hook and defended as somehow consistent with the values underlying the text taken at an appropriate level of generality. ${ }^{12}$ Enthusiasts of a hard unitary executive, however, most frequently link their interpretation to one or another form of originalism that is taken to be genuinely constraining. Indeed, judicial constraint is widely taken to be originalism's central value. ${ }^{13}$ Old originalism, which might also be called intent-based originalism, seeks to find behind the constitutional text the founding generation's expectations for the application of that text. Perhaps the most glaring example of intentbased originalism in the Supreme Court is its reading of the Eleventh

12 See generally JACK M. BALKIn, LIVING ORIGINALISM 3 (2011) (offering a view of the Constitution "as an initial framework for governance that sets politics in motion, and that Americans must fill out over time through constitutional construction”); Thomas B. Colby \& Peter J. Smith, Living Originalism, 59 Duke L.J. 239 (2009) (arguing that while originalists agree on the importance of looking to the text, how to operationalize the text has been a point of disagreement).

13 See ANTONIn SCALiA, A MATTER OF INTERPRETATION: FEDERAL COURTS AND THE LAW 46-47 (1997) (arguing that originalism precludes the use of evolving standards in constitutional interpretation). To be "constrained" in constitutional interpretation, however, is not necessarily the same thing as being "restrained" in the exercise of judicial power to overcome the judgments of elected officials. See Keith E. Whittington, The New Originalism, 2 GEO. J.L. \& PUB. POL'Y 599, 609 (2004) (explaining that defenders of the "new originalism" take constitutional fidelity, not judicial restraint, to be the normative value underpinning their methodology). For an intellectual history of modern-day originalist theory, together with a supremely helpful analysis of disagreements within the "family" of originalist approaches, see Lawrence B. Solum, Originalism and Constitutional Construction, 82 FORDHAM L. REV. 453, 456 (2013) (explaining that, while all versions of originalism share the ideas that constitutional meaning is fixed at the time of drafting and ratification and that this meaning should constrain political officials, originalist approaches may differ in many other respects). 
Amendment. In quite specific language, ${ }^{14}$ the Amendment does no more than renounce jurisdiction over cases brought against states in federal court by citizens of other states. The Supreme Court has held, however, that the intent behind the Eleventh Amendment was to restore a tacit baseline understanding among the Framers concerning the states and sovereign immunity generally. ${ }^{15}$ In view of this imputed intent, the Court reads the Constitution as not authorizing suits brought against a state, whether by its own citizens or citizens of other states, and whether in state or federal court. ${ }^{16}$ The only exceptions would be suits brought under federal statutes enacted pursuant to congressional remedial powers added to the Constitution after the Eleventh Amendment was ratified. ${ }^{17}$

Critics of old originalism have discussed at length the difficulty of finding a coherent collective intent behind a document, the legal status of which reflects not only the handiwork of its drafters, but also the expectations of the various state ratifying conventions. ${ }^{18}$ Old originalism has also been critiqued as ironically inconsistent with the founding generation's preferred methods of interpretation. ${ }^{19}$

Largely in response to these critiques, a new originalism has emerged, which purports to be linked to the so-called "original public meaning" of the relevant text. Original public meaning is said to be the meaning of the text as it would have been understood by then-contemporary competent readers in the population at large, as evidenced by dictionaries or other indicators of

14 "The Judicial power of the United States shall not be construed to extend to any suit in law or equity, commenced or prosecuted against one of the United States by Citizens of another state, or by Citizens or Subjects of any Foreign State." U.S. CONST. amend. XI.

15 See, e.g., Alden v. Maine, 527 U.S. 706, 722 (1999) ("The text and history of the Eleventh Amendment... suggest that Congress acted not to change but to restore the original constitutional design.”); Hans v. Louisiana, 134 U.S. 1, 15-16 (1890) (“[T]he cognizance of suits and actions unknown to the law ... was not contemplated by the Constitution when establishing the judicial power of the United States.... The suability of a State without its consent was a thing unknown to the law.").

16 See, e.g., Alden, 527 U.S. at 712 (holding that Congress's authority under Article I does not encompass "the power to subject nonconsenting [s] tates to private suits for damages in state courts"); Hans, 134 U.S. at 20-21 (holding that a state's own citizens may not bring suit against it in federal court without its consent).

17 See generally Fitzpatrick v. Bitzer, 427 U.S. 445 (1976) (allowing private causes of actions against states when the cause of action is enacted pursuant to the Fourteenth Amendment).

18 See, e.g., Paul Brest, The Misconceived Quest for the Original Understanding, 60 B.U. L. REV. 204, 214 (1980) ("Therefore, an intentionalist must necessarily use circumstantial evidence to educe acollective or general intent.").

19 See generally H. Jefferson Powell, The Original Understanding of Original Intent, 98 HARV. L. REV. 885, 887 (1985) (explaining that originalism emerged as a form of interpreting the Constitution only during the administration of President John Adams). 
popular usage..$^{20}$ New originalism resonates with old originalism in that its advocates would insist that original public meaning is also the best evidence of intent. But, in any event, to the extent there is an ascertainable original public meaning, that meaning would presumably be what people voting on ratification thought they were voting for or against. ${ }^{21}$

Applying this-or actually, any-interpretive method to the unitary executive debate is complicated in some easy-to-overlook ways. First, in asking whether the Vesting Clause mandates a hard version of the unitary executive, we are asking what that clause implies in answer to two questions: Does the President have a constitutionally mandated power to remove at will any and all officers of the executive branch? And does the President have constitutionally vested authority to effectively carry out all statutory law himself by dictating how every other officer in the executive branch exercises his or her legally vested discretion? These are not questions that can be resolved simply by ascertaining the literal or semantic meaning of the words that the clause uses. It is a safe bet that no dictionary definition of "executive power," either in the 1780s or now, will define "executive power" in a sufficiently unambiguous way to yield a determinate answer to the question of the Vesting Clause's legal effects. What we are searching for might better be described as a "construction" of the clause-that is, a resolution of any vagueness or ambiguity in the text's semantic meaning by resort to evidence other than the words' acontextual communicative content. $^{22}$

20 "[T] he new originalism is focused less on the concrete intentions of individual drafters of constitutional text than on the public meaning of the text that was adopted." Whittington, supra note 13, at 609. Prominent judicial examples of what purports to be the method at work include District of Columbia v. Heller, 554 U.S. 570 (2008) and NLRB v. Noel Canning, Co., 134 S. Ct. 2550, 2592-618 (2014) (Scalia, J. concurring).

21 A fascinating complication has been introduced into the scholarly debate over new originalism by evidence that a substantial number of voters in New York and Pennsylvania were informed largely by versions of the Constitution that appeared in Dutch and German translations, respectively. This introduces the prospect that, in important ways, English-speaking and non-English-speaking voters during the ratification period may well have understood the Constitution differently. See generally Christina Mulligan et al., Founding-Era Translations of the U.S. Constitution, 31 CONST. COMmENT. 1 (2016) (using translations of the Constitution made at the founding to derive the meaning of the text as understood by the translators).

22 On the relationship between interpretation and construction, see generally Solum, supra note 13 (explaining that the indeterminacy of the constitutional text frequently requires other interpretive tools besides strict construction, in which the plain meaning of the text is simply translated). Professor Solum argues that "construction is ubiquitousconstitutional practitioners always engage in constitutional construction when they apply the constitutional text to particular cases or problems. . . [T] he construction zone is ineliminable; there is no convincing argument that any plausible approach to constitutional interpretation will eliminate the underdetermination of constitutional practice by squeezing more communicative content from the constitutional text." Id. at 
Understanding the unitary executive debate in these terms, however, highlights what Richard Fallon has identified as an ambiguity in what scholars mean when they purport to identify "original public meaning." ${ }^{23} \mathrm{He}$ persuasively shows how "legal meaning" might be understood in at least half a dozen different ways, so that debates over interpretation can rest on disagreement over which form of legal meaning counts and what the relevant evidence shows once we have alighted on the right meaning of "original meaning." Of the "meaning[s] of legal 'meaning"" that Professor Fallon identifies, one seems most apt in capturing what "new originalism" defenders of the unitary executive are arguing. That is, new originalists are arguing for a construction of Article II that treats the "unitary executive" as equivalent to the " $[c]$ ontextual meaning [of the Vesting Clause] as framed by the shared presuppositions of speakers and listeners, including shared presuppositions about application and nonapplication." ${ }^{24}$ This coincides with Professor Lawrence Solum's statement of the "Public Meaning Thesis," namely, "that the communicative content of the constitutional text is determined by the semantic meaning of the text as enriched by the publicly available context of constitutional communication. ${ }^{25}$

Merely identifying old and new originalism, however, still leaves unanswered many important questions about originalist interpretation. Some questions have to do with the plausibility of the method ${ }^{26}$ and some

495. Experience, as well as the force of Professor Solum's logic, persuades me that his position is correct.

23 Richard H. Fallon, Jr., The Meaning of Legal "Meaning" and Its Implications for Theories of Legal Interpretation, 82 U. CHI. L. REV. 1235 (2015) (emphasis added) (critiquing textualism and originalism as unable to make consistent, categorical selections among possible referents for claims of legal meaning).

24 Fallon, supra note 23, at 1246.

25 Solum, supra note 13, at 474. I suspect that Professor Solum would object to my formulation as conflating his important distinction between "interpretation" and "construction"; his statement of the "Plain Meaning Thesis" is, within his framework, a statement about what the words convey (interpretation), not about the determination of their legal effect (construction). But when defenders of the unitary executive thesis argue from the original public meaning of Article II, their arguments are most readily understood as equating the "communicative content" of Article II-which Professor Solum links to its semantic content-with Article II's proper "construction." Indeed, following Professor Solum, "original public meaning" originalism might better be called "original public construction" originalism. See Solum, supra note 13, at 457 (defining constitutional construction as "the activity that determines the content of the constitutional doctrine and the legal effect of the constitutional text"). I believe, however, or at least hope, that my restatement of the new originalist argument for the unitary executive captures in at least a relatively clear and intuitively appealing way the strategy of that argument.

26 See generally Jack M. Balkin, The Construction of Original Public Meaning, 31 Const. COMMENT. 71 (2016) (putting forth six different ways original public meaning could be understood). 
with its normative underpinnings. That is, even if it were possible to identify founding intent or original public meaning, it would still be debatable why either should govern contemporary application of the Constitution. And, of course, once one makes the move from interpretation to construction, one's approach to constitutional construction would also have to be normatively justified.

For present purposes, this Article will not pursue in further depth either the plausibility of, or normative questions surrounding old or new originalism, but, in a sense, take each method as commonly understood. I shall accept that a coherent search for original public meaning is possible and can sometimes identify communicative content that is not, to use another phrase of Professor Solum's, "vague, ambiguous, gappy, or contradictory." ${ }^{27}$ What history shows, however, is that the semantic meaning of Article II's Executive Power Vesting Clause is at least the first two of those things, and that the original construction of executive power vesting clauses did not attribute to them the unitary executive as the original construction.

\section{Public MEANing ORIGinalism AND the EARLy STATE CONSTITUTIONS}

An original public meaning strategy for imputing a mandatory unitary executive to Article II has to demonstrate that, in creating our separation of powers system, the founding generation would necessarily have inferred from the Constitution's contextual meaning that a unitary executive is a necessary corollary to the separation of powers. It might appear that the threshold issue for such an approach would be identifying the words of the Constitution that are relevant to the inquiry. Should we seek, for example, the semantic meaning of the "vest[ing] of executive power?" Or is our appropriate focus the original meaning of the vesting of executive power, when combined with an explicit obligation to "take care that the Laws be faithfully executed," or perhaps when combined with both the faithful execution obligation and the right to demand the opinions in writing of

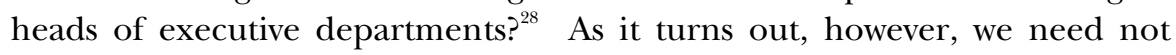
settle on a single focus because the early constitutions, with or without these

27 Lawrence Solum, Semantic and Normative Originalism: Comments on Brian Leiter's “Justifying Originalism, "LEGAL THEORY BLOG (Oct. 30, 2007, 1:30 AM), http://lsolum.typepad.com/ legaltheory/2007/10/semantic-and-no.html; see also Solum, supra note 13, at 469-70 ("A text is ambiguous if it can have more than one meaning .... The words 'ambiguity' and 'vagueness' are sometimes used interchangeably, but I am now referring to 'vagueness' in the technical (or more precise) sense in which it refers to expressions that have borderline cases.").

28 U.S. CONST., art. II, § 3. 
additional clauses, demonstrate that the unitary executive model was not the original construction of the vesting of executive power in a chief executive. ${ }^{29}$

For evidence of what these clauses meant to late eighteenth century readers, I take as my evidence a set of early state constitutions roughly contemporaneous with the Philadelphia draft. As I said earlier, one is unlikely to find in any dictionary-then or now-a definition of "executive power" that encompasses precisely what hard unitary executive advocates claim. One does find the definition in Samuel Johnson's dictionary, "having the power to put in act the laws." ${ }^{30}$ Such a formulation, however, leaves ambiguous the key questions surrounding unitary executive theory, namely, does the Chief Executive have comprehensive removal authority over all subordinate administrators, and may the Chief Executive command those administrators in their exercise of any discretion that the law gives them with regard to government action?

29 To be clear, my position does not deny that the President enjoys some degree of constitutionally-based supervisory authority over subordinate officers. To the extent subordinate officers help in implementing specific powers vested in the President by the Constitution, the argument is strong that the President's powers of control over such officers must be complete. For example, Professor Prakash and I would no doubt agree that the Secretary of State could not be protected from at-will discharge. Likewise, I assume the President must have complete control over the policy judgments entailed in the implementation of any congressional authority to negotiate, for example, an international trade deal. Further, even dissenters from the unitary executive thesis would concur that the President's faithful execution obligation, U.S. CONST. art. II, § 3, requires that presidents have authority to dismiss administrative officers for dereliction of duty. See Morrison v. Olson, 487 U.S. 654, 692 (1988) ("[W]e [do not] think that the 'good cause' removal provision at issue here impermissibly burdens the President's power to control or supervise the independent counsel, as an executive official, in the execution of his or her duties under the Act. This is not a case in which the power to remove an executive official has been completely stripped from the President, thus providing no means for the President to ensure the 'faithful execution' of the laws.").

My interpretive inferences are these: The Constitution does not guarantee the President complete policy control over the implementation of statutes that do not directly implicate his specific Article II powers. Because the Constitution, for example, gives the President no authority over the economy, it is up to Congress how far the President may personally be involved in controlling those administrators who implement statutes that Congress enacts pursuant to its power to regulate commerce. The President undoubtedly has entitlements to information, pursuant to the Opinions Clause, U.S. CONST. art. II, § 2, CL. 1 , and presumably some powers of coordination under the Vesting Clause. But whether (a) presidents may personally exercise the functions Congress has vested in this class of administrators, (b) command how such administrators exercise their policy discretion, or (c) remove such administrators solely on grounds of policy preference, are matters subject to congressional determination. These inferences are derived, however, not only or even primarily from text, but rather from arguments rooted in institutional structures and relationships and a general normative commitment to checks and balances. SHANE, supra note 2, at 5-6 (defending checks and balances).

30 Calabresi \& Prakash, supra note 7, at 580 (quoting 1 SAMUEL JoHnson, A DictionARY OF THE ENGLISH LANGUAGE 684 (4th ed. 1773)). 
Dictionaries, at least in this instance, are hardly the best, much less an exclusive source of interpretive guidance on questions such as these, which really go to a text's legal effect or operational consequences. A common popular understanding of the significance of words in operation is most likely to arise when the language at issue is in common use, and people can observe in action the significance of the text in question. A common hypothetical posed to students of statutory interpretation is whether a sign banning "vehicles" in a park should be read as a bar to bicycle riding. If, in any particular city, one observes that bicycle riding is common in parks bearing such signs, one would likely conclude that, within such an interpretive community, "vehicle" in the specific context of park signage does not connote "bicycle," irrespective of contemporary dictionaries. As it happens, because language nearly identical to the federal Constitution appears regularly in contemporaneous state constitutions, we can readily investigate whether those documents and government practice under them reveal what Americans who read the relevant clauses took them to imply. The Supreme Court, when it pursues original public meaning, looks to state constitutions for just such evidence. $^{31}$

Of course, any examination of the early state constitutions has to begin by identifying the relevant documents. There is no fixed time frame within which semantic understandings and their legal implications remain relatively stable. For reasons of both plausibility and manageability, I have thus focused on states admitted to the Union within fifteen years of the drafting of the federal Constitution-in other words, by 1802. Then, even though the United States comprised seventeen individual states by 1802, I excluded Rhode Island. Rhode Island famously operated under its seventeenth century charter until $1842,{ }^{32}$ and documents drafted so remotely from 1789 might not be trustworthy indicators of 1787-1789 meaning. For the remaining sixteen states, I focused on the state constitutions drafted most closely in time to the federal Constitution, except for six states that did not draft post-Confederation Period constitutions until well into the nineteenth century, if at all (Maryland, Massachusetts, New Jersey, New York, North Carolina, and Virginia). ${ }^{33}$ For those states, I included whichever of their Confederation Period constitutions was drafted most closely to 1787 .

31 See, e.g., District of Columbia v. Heller, 554 U.S. 570, 600-01 (2008) ("Our interpretation is confirmed by analogous arms-bearing rights in state constitutions that preceded and immediately followed adoption of the Second Amendment.").

32 Maureen McKenna Goldberg, Rhode Island's Unique Constitutional History, 72 ALB. L. Rev. 601, 602 (2009).

33 The constitutional texts on which I relied appear in 1-7 THE FEDERAL AND STATE Constitutions, Colonial Charters, and Other Organic LaWs of the States, Territories, AND COlONiEs NOW OR Heretofore Forming the United States of AMERICA (Francis Newton Thorpe ed., 1909). 
The one state for which this strategy did not yield a text drafted within thirteen years of federal ratification is Connecticut, which continued to operate throughout the Confederation and early national periods under its 1662 Charter. $^{34}$ Its organic document closest in time to 1787 was its 1818 Constitution, which I did include in my sample. Here is the list of constitutions thus reviewed and their dates of ratification:

\begin{tabular}{|l|l|}
\hline CONNECTICUT & 1818 \\
\hline DELAWARE & 1792 \\
\hline GEORGIA & 1789 \\
\hline KENTUCKY & 1792 \\
\hline MARYLAND & $1776($ NEXT CONSTITUTION $=1851)$ \\
\hline MASSACHUSETTS & $1780($ STILL IN OPERATION $)$ \\
\hline NEW HAMPSHIRE & 1792 \\
\hline NEW JERSEY & $1776($ NEXT CONSTITUTION $=1844)$ \\
\hline NEW YORK & $1777($ NEXT CONSTITUTION $=1821)$ \\
\hline NORTH CAROLINA & $1776($ NEXT CONSTITUTION $=1868)$ \\
\hline OHIO & 1802 \\
\hline PENNSYLVANIA & 1790 \\
\hline SOUTH CAROLINA & 1790 \\
\hline TENNESSEE & 1796 \\
\hline VERMONT & 1793 \\
\hline VIRGINIA & $1776($ NEXT CONSTITUTION $=1830)$ \\
\hline &
\end{tabular}

Including state institutions in the analysis from both before and after 1787 would seem to be a good thing from a public meaning point of view. To the extent the federal Constitution employs language similar to its forebears, we may infer that the Philadelphia drafters understood their words to have similar import. To the extent post-Philadelphia state constitutions use language similar to the federal Constitution, we can draw inferences by looking at those state constitutions as to how the states interpreted the words of the federal Constitution's Article II. All in all, if state constitutions consistently vest "executive power" in a governor, both before and after 1787, and if the original public meaning of "executive power" included unitary policy control over discretionary executive functions, one would expect to find such functions located reliably within governor-headed hierarchies in the states. One would also expect such

34 For an intriguing account of the debates that continued reliance on the Charter engendered in Connecticut between independence and the ultimate calling of a constitutional convention in 1818, see J. HAMmOND TRUMBUll, Historical Notes ON THE CONSTITUTIONS OF CONNECTICUT 1639-1818 (Hartford, Brown \& Gross 1873). 
functions to be primarily accountable to the governor in the ordinary working of state administration. On the other hand, if state constitutions consistently vest "executive power" in a governor, both before and after 1787 , but remove areas of public administration from gubernatorial control (or allow state legislatures to do so), then we would likely conclude that the vesting of executive power in a chief executive was not understood to entail a hard version of a unitary executive. The latter pattern is the one that the early documents reveal, both before and after 1787 .

In fact, despite executive power vesting clauses, each of the sixteen constitutions in the sample contemplates either a mandatory or permissive legislative role in the appointment of officials involved in public administration. In Connecticut, the state's treasurer and secretary were elected officials; the legislature appointed the state's comptroller and sheriffs. ${ }^{35}$ In Delaware, the state's treasurer was appointed by the legislature; the constitution reserved power to the legislature to prescribe methods of appointment for "[a]ttorneys at law, all inferior officers in the treasury department, election officers, officers relating to taxes, to the poor, and to highways, constables and hundred officers...." ${ }^{36}$ Georgia's constitution provided for gubernatorial appointments of militia officers, secretaries of the governor, and such inferior officers as the legislature might permit the governor to appoint; by implication, all principal officers would be appointed by the legislature. ${ }^{37}$

The state legislatures of Kentucky, Maryland, and Pennsylvania appointed those states' treasurers. ${ }^{38}$ In New Jersey, a legislative council and the general assembly together appointed the attorney-general, secretary, and treasurer. $^{39}$ The South Carolina General Assembly appointed "commissioners of the treasury, secretary of the State, and surveyorgeneral." The legislature of Massachusetts appointed the "Secretary, Treasurer, and Receiver-General, and the Commissary-General, Notaries public, and Naval-Officers." ${ }^{41}$ In New Hampshire, likewise, the legislature selected the "secretary, treasurer, and commissary-general." ${ }^{42}$ Moreover, the governor shared his appointments powers with regard to other officers with a popularly-elected five-member council, which could veto his

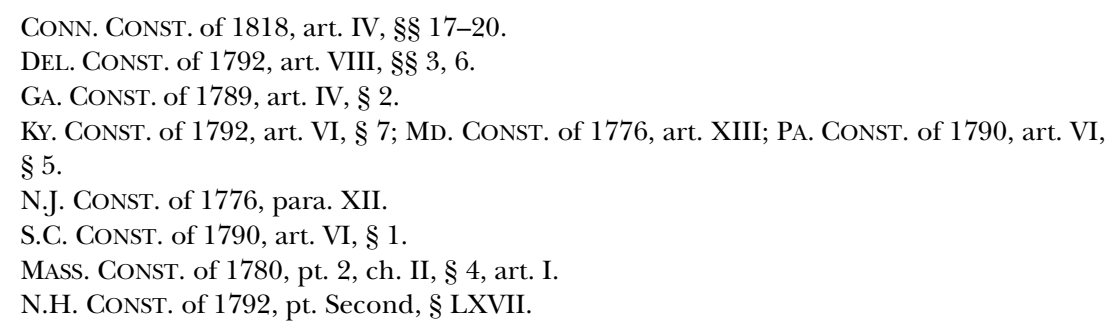


appointments. ${ }^{43}$ In New York, the legislature appointed the treasurer, ${ }^{44}$ and the governor shared his appointment power with a council of four Senators. ${ }^{45}$ The North Carolina legislature appointed both that state's Attorney General and its Treasurer. ${ }^{46}$ The Ohio legislature appointed the secretary of state, the treasurer, and the auditor. ${ }^{47}$ The Virginia legislature appointed the state's attorney general, secretary, and treasurer. ${ }^{48}$ In Tennessee, the Governor was assigned appointment authority with regard to the adjutant-general of the militia, but the 1796 Constitution provided that " $[t]$ he appointment of all Officers, not otherwise directed by this Constitution, shall be vested in the Legislature." ${ }^{49}$ Vermont's constitution did not explicitly vest appointment power over administrators to anyone other than the governor and his council. It envisioned, however, that the legislature could itself decide to vest appointment power elsewhere. The constitution vests the power of appointment in the governor and his council for all "Officers, except where provision is, or shall be otherwise made, by law or this Frame of Government., ${ }^{50}$ As described below, the Vermont legislature proceeded to exercise such authority in a constitutionally interesting way. ${ }^{51}$

This pattern is all the more striking because, in ten of these states, the constitutions explicitly and without qualification vested the "executive power" or the "supreme executive power" of the state in a governor. ${ }^{52}$ Presumably, the Massachusetts and New Hampshire constitutions were to the same effect, although, rather than vesting executive power, they denominated their governors to be "the supreme Executive Magistrate." ${ }^{, 53}$ In Virginia, the Governor exercised "the executive powers of government," but with the advice of a Council of State. ${ }^{54}$ The Maryland and North Carolina constitutions provided that their governors could exercise "the executive

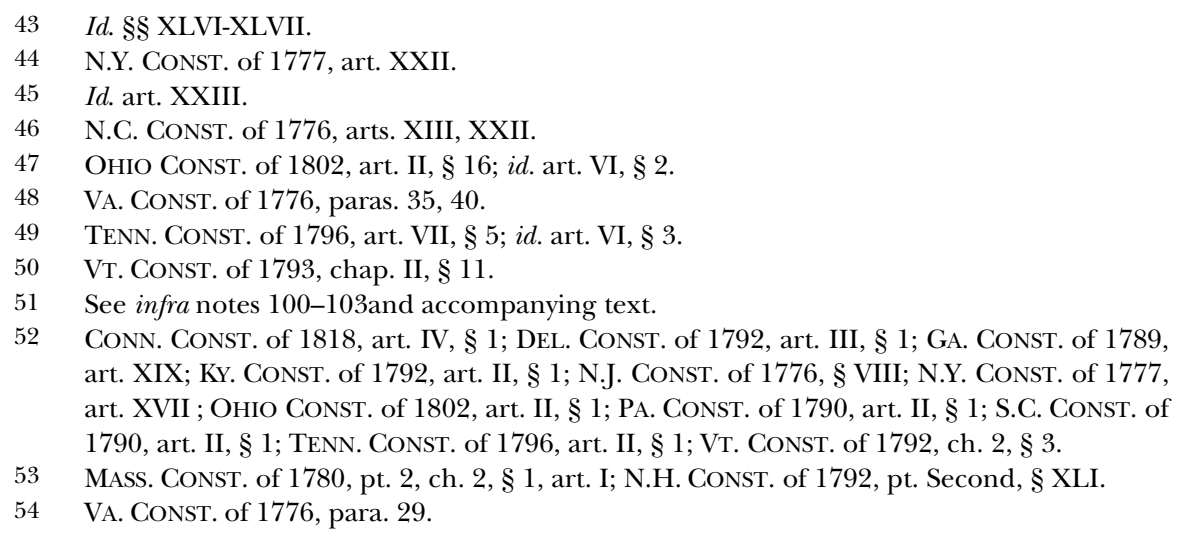


powers of government," but noted that those powers could be limited by the constitution or were to be exercised "according to the laws of [the] State.",55

Yet even those state constitutions that arguably vested executive authority with some linguistic ambiguity offer no solace to proponents of a hard unitary executive reading of the federal Constitution. That is because these are also five of the early constitutions in the sample that include explicit commitments to the separation of powers that are actually stronger and more categorical than any text in the federal constitution. Both Maryland and North Carolina accompanied their 1776 state charters with Declarations of Rights that, in nearly identical terms, affirmed " $[t]$ hat the legislative, executive and supreme judicial powers of government, ought to be forever separate and distinct from each other. ${ }^{56}$ The 1776 Virginia Bill of Rights likewise provided that "the legislative and executive powers of the State should be separate and distinct from the judicative...., ${ }^{, 57}$ Likewise, according to the Constitution of Massachusetts:

In the government of this [c] ommonwealth, the legislative department shall never exercise the executive and judicial powers, or either of them; [t] he executive shall never exercise the legislative and judicial powers, or either of them; [t] he judicial shall never exercise the legislative and executive powers, or either of them; to the end it may be a government of laws and not of men.

Most elaborately, New Hampshire provided:

In the government of this State, the three essential powers thereof, to wit, the [1] egislative, [e]xecutive, and [j]udicial, ought to be kept as separate from, and independent of each other, as the nature of a free government will admit, or as is consistent with that chain of connection that binds the whole fabric of the [c] onstitution in one indissoluble bond of union and amity.

It would seem anomalous to treat the non-conforming appointments in these states as evidence of a lesser commitment to the drafters' own conceptions of the separation of powers, when each of these states declared its commitment to the separation of powers so emphatically—at least if we are taking seriously the idea of "original public meaning."

That non-conforming appointments are sanctioned in sixteen state constitutions that vested executive power in a governor-often reinforced by explicit commitments to the separation of powers-would seem to devastate the thesis that the vesting of executive power is enough, by virtue of original public meaning, to assure the Chief Executive unitary policy control over all public administration. It remains to be considered, however, whether the federal Constitution might be semantically distinct, however, because it

55 MD. CONST. of 1776, para. XXXIII; N.C. CONST. of 1776, para. XIX.

56 N.C. CONST. of 1776, Declaration of Rights, para. IV ; MD. CONST. of 1776, Declaration of Rights, para. VI (using the same language as the North Carolina constitution, with the exception of the word "supreme").

57 VA. CONST. of 1776 , Bill of Rights, $\S 5$.

58 MASs. CONST. of 1780 , pt. 1, art. XXX.

59 N.H. CONST. of 1792, pt.1, art. XXXVII. 
contains two other provisions that arguably yoke public administration to the President personally. One is the requirement that the President "take Care that the Laws be faithfully executed." require the Opinion, in writing, of the principal Officer in each of the executive Departments, upon any Subject relating to the Duties of their respective Offices." ${ }^{61}$

These inquiries, however, do not buttress the unitary executive thesis. Governors in nine states are explicitly required to take care that the laws be faithfully executed. ${ }^{62}$ In those states, it is obvious that the presence of an express faithful execution obligation was not thought inconsistent with giving state legislatures powers of appointment with regard to important civil officers. It is arguable, moreover, that this figure understates the irrelevance of faithful execution clauses to the unitary executive. That is because it is unclear historically whether faithful execution clauses were intended as sources of executive authority or rather merely as prohibitions against the executive suspension of statutes. ${ }^{63}$ If the latter reading of such clauses is

$60 \quad$ U.S. CONST. art. II, $\$ 3$.

$61 \quad$ Id. art. II, § 2, cl. 1 .

62 CONn. CONST. of 1818, art. IV, § 9; DEL. CONST. of 1792, art. III, § 13; KY. CONST. of 1792, art. II, § 14; N.Y. CONST. of 1777 , art. XIX; OHIO CONST. of 1802, art. II, § 7; PA. CONST. of 1790 , art. II, $\S 13$; S.C. Const. of 1790, art. II, § 8; TENN. CONST. of 1796, art. II, § 10; VT. CONST. of 1793, ch. II, § 11.

63 Charles Tiefer, The Constitutionality of Independent Officers as Checks on Abuses of Executive Power, 63 B.U. L. REV. 59, 90 (1983) ("[T] he Framers probably included the "faithful execution' clause in the Constitution to limit, not expand, the President's power."). Professor Prakash has an unusual argument as to why, contrary to a common scholarly view, the Faithful Execution Clause would not have been understood as a ban on the suspension of statutes. He points out that the English Bill of Rights, 1689, 1 W. \& M., c. 2 (Eng.), which barred the royal suspension of statutes, was enacted in 1689 . Yet the Pennsylvania Constitution of 1682 already provided: "That the Governor and provincial Council shall take care, that all laws, statutes and ordinances, which shall at any time be made within the said province, be duly and diligently executed." FRAME OF THE Government of PENnSYLVANIA, art. VIII (1682). A 1682 colonial constitution obviously could not have been derived from a 1689 parliamentary enactment. PRAKASH, THE CONSTITUtion of the ORIGinal EXecutive, supra note 5, at 93. If the Pennsylvania Constitution were the model for Article II's Faithful Execution Clause, then Article II would also not have roots in the English Bill of Rights.

The problem with this argument is that a number of state constitutions were written much closer in time to 1787 , e.g., N.Y. CONST. of 1777, and they contained faithful execution clauses, e.g., id. cl. XIX, that were at least as likely to be on drafters' minds in 1787 as models for Article II. It is dubious to assume that drafters of constitutions written in the 1770s would have understood the requirement of faithful execution to mean no more and no less than it meant in 1682, notwithstanding the momentous developments of 1689 , which were of undoubted import to the colonists in understanding their liberties as British subjects. Even without critically important intervening events, the passage of time can alter what language signifies. When Thomas Jefferson spoke of the "pursuit of happiness" in 1776, he probably meant something like the pursuit of excellence and a virtuous life. Carol V. Hamilton, Why Did Jefferson Change "Property" to the "Pursuit of 
correct, it is notable that the four of the state constitutions that vest administrative appointments in authorities other than the governor but omit faithful execution clauses nonetheless expressly prohibit the executive suspension of statutes. ${ }^{64}$ Under this view of faithful execution, thirteen of the sixteen constitutions not only vest executive power in a governor, but also impose a faithful execution obligation or its equivalent. There is little here to buttress the notion that drafters of state constitutions equate the vesting of executive power and the obligation of faithful execution of the laws with hierarchical control of public administration directed solely by the governor.

Nor does the picture change if we look at constitutions that entitle governors to demand reports from other administrators. From my sample, it appears as if the federal Opinions Clause may have been a new invention. None of the six Confederation Period state constitutions in my sample has its equivalent. Of the ten post-Philadelphia constitutions, drafters of which might have consulted the federal text as an example, seven of these do include equivalent provisions. ${ }^{65}$ The only difference is that each of these texts, instead of entitling the respective governors to "opinions" in writing, allows the governors to demand "information" in writing. All in all, Connecticut, Delaware, Kentucky, Ohio, Pennsylvania, South Carolina, and Tennessee provide seven examples of state constitutions roughly contemporaneous with, but drafted later than, the federal Constitution that all conjoin executive vesting clauses, faithful execution clauses, and the equivalent of the federal Opinions Clause. Yet each of these state

Happiness"? HistORY NEWs NETWORK (Jan. 27, 2008), http://new.hnn.us/article/46460. When twenty-first century politicians speak of the "pursuit of happiness," they presumably mean something quite different, even in quoting Jefferson.

Nor is it especially revealing that a state constitution might contain both a faithful execution obligation and a ban on suspending statutes. VT. CONST. of 1786, ch. II, art. XI; $i d$. ch. I, art. XVII. Constitutions are sometimes simply redundant. Cf. PrAKASH, THE CONSTITUTION OF THE ORIGINAL EXECUTIVE, supra note 5, at 193 (acknowledging that the Opinions Clause is seemingly superfluous given the Executive Power Vesting Clause). Indeed, if the Faithful Execution Clause is, as Professor Prakash suggests, not a ban on the suspension of statutes, but an affirmative grant of authority to the President to execute the law, the Faithful Execution Clause would seem to be a mere reiteration of the meaning Professor Prakash already ascribes to the Executive Power Vesting Clause. Moreover, even if the Vesting Clause did not already imply a requirement of fidelity to law, which seems doubtful, the presidential oath to "faithfully execute the Office of President of the United States" would seem to have fully covered the point. U.S. CONST. art. II, $\S 1$.

64 Mass. CONST. of 1780, pt. First, art. XX; N.H. CONST. of 1792, pt. I, art. XXIX; N.C. CONST. of 1776, Declaration of Rights, art. V; VA. CONST. of 1776, Bill of Rights, § VII.

65 Conn. Const. of 1818 , art. IV, $\S 6$; DEL. Const. of 1792, art. III, $\S 10$; Ky. CONST. of 1792 , art. II, $\S 11$; OhIO CONST. of 1802, art. II, $\S 7$; PA. Const. of 1790 , art. II, § 10; S.C. CONST. of 1790 , art. II, $\S 11$; TENN. CONST. of 1796 , art. II, $\S 8$. 
constitutions expressly assigns to the legislative branch at least some of the appointing power with regard to significant administrative officers. ${ }^{66}$

66 Not much is added to this analysis by an inquiry into gubernatorial removal powers. The federal Constitution, of course, makes no mention of presidential removal power. This is the pattern of most state constitutions as well, except insofar as they authorize gubernatorial removals of judicial or militia officers on address by two-thirds of a few of the state legislatures. In Delaware, the attorney general was subject to such removal by address, but that constitution clearly implies that the attorney general is part of the judiciary; that official is grouped, with regard to removal susceptibility, with "clerks of the supreme court, prothonotaries, registers, clerks of the orphans' courts and of the peace," all of whom are part of the judicial branch of government. DEL. CONST. of 1792, art. VIII, $\S 5$. The only constitutions that explicitly contemplate a general gubernatorial removal power are those of Maryland and Vermont. In Maryland, the Governor could "suspend or remove any civil officer who has not a commission during good behavior," with the approval of the Governor's Council, both the Governor and his Council having been elected by the legislature. MD. CONST. of 1776, para. XLVIII. Vermont's constitution provided that "[e]very officer of state, whether judicial or executive, shall be liable to be impeached by the General Assembly, either when in office, or after his resignation or removal for mal-administration." VT. CONST. of 1793, Ch. II, § 24. Uniquely, it went on to prove that "[a]ll impeachments shall be before the Governor, or Lieutenant Governor, and Council ...." Id. In every other state, impeachment was the prerogative of the legislature.

Although what these texts imply for a governor's authority to remove officers-and thus, perhaps, to supervise their exercise of discretionary functions-is not entirely clear, the implications seem to disfavor the unitary executive idea. For example, federal courts have long assumed that, in the absence of any implicit or explicit statutory constraint on the President, the President's power of removal would be incidental to the power of appointment. Ex parte Hennen, 38 U.S. 230, 259 (1839) ("In the absence of all constitutional provision, or statutory regulation, it would seem to be a sound and necessary rule, to consider the power of removal as incident to the power of appointment."). If that is so, it would seem to follow that, where state constitutions vested appointment authority in state legislators, they and only they would likewise have the power of removal. Any gubernatorial authority over such officers would be limited to what the respective constitutions might have provided or what the relevant legislatures might have authorized by statute.

Some state statutes were a bit more detailed about official accountability to the legislature. Kentucky, as noted above, was one of the states in which the legislature chose the treasurer. That official, in turn, reported directly to a committee appointed by the legislature. An early statute provided that the Kentucky treasurer "forfeit[ed] his office" if he misapplied any funds, presumably upon a resolution of the legislature to that effect. Acts of the General Assembly of Ky., Jan. Sess. 1798, ch. LXV, §§ 11-12. The Kentucky Constitution contained no provision for the removal of delinquent officers by the governor. The South Carolina Constitution of 1790 carried forward the provisions of the state's 1778 Constitution providing for the legislative appointment of the "commissioners of the Treasury," along with the attorney-general and other officers, subject to such future changes as the legislature might enact. S.C. CONST. of 1790, art. VI, § 1 ; id. art. VII. Not only does there appear to be no legal provision for the gubernatorial removal of the two state treasurers-one in Columbia and one in Charleston-but these officials had the duty to "instruct the attorney-general or solicitors, respectively, to prosecute ... defaulters" among the state's tax collectors. Act of Dec. 19, 1801, 1801 S.C. ACTS 1, 12. Thus, the supervision of tax collection-which we would today regard as quintessentially executive-was in the hands of officials who reported only to the 
In sum, early state constitutions vested "executive power" in a governor, but did not assign all administrative officers to a governor-headed executive branch hierarchy. Critical executive functions are assigned to officers who appear not to be accountable to state governors in the ordinary workings of public administration. The most natural reading of these texts belies unitary executive theory as a matter of original public meaning. As a theoretical matter, however, it is hypothetically possible that the evidence thus amassed might actually buttress, rather than undermine, a unitary reading of the federal Constitution. The next Part of this Article explains-and refutesthis argument.

\section{AdMINISTRATIVE Practice Under THE EARLY STATE CONSTITUTIONS}

A counterargument to Part II's reading of the early state constitutions could run as follows: The original public meaning of an Executive Power Vesting Clause, either alone or in combination with the Faithful Execution and Opinions Clauses, would have dictated a unitary executive interpretation in the late eighteenth century, unless qualified by other clauses. The fact that all the early state constitutions provide expressly for the legislative appointment of various officers might demonstrate that, absent such explicit provisions, the state legislatures would have been required under original public meaning to acknowledge an exclusive appointment authority in the governor-as well as the removal and supervisory authorities for which unitary executive advocates argue. Because the federal Constitution does not provide for the legislative appointment of various officers, it would follow, under this theory, that the unitary executive construction of that document is the right one. ${ }^{67}$

legislature. They, in turn, could "direct" the filing of suit, which we would today typically classify also as an executive function.

In sum, the early state constitutional texts pertaining explicitly to removal powers generally do not add anything to an original public meaning argument for a unitary executive in the states, but the topic is generally left to implication, as it is in the federal Constitution.

67 From our correspondence, I take this to be Professor Prakash's position:

The unitary executive claim is not that the vesting of executive power necessarily cedes control over the public administration of the law.... [C] onstitutions can modify that rule as by granting for cause removal constraints or by implying that those vested with executive power cannot direct. The [unitary executive] claim is that the U.S. Constitution has no such constraints and that Congress cannot modify the President's power to serve as "constitutional executor" of the law any more than it can modify the President's pardon power.

Email from Saikrishna Prakash to Peter M. Shane (June 20, 2016, 10:43 EST) (on file with the author). 
To be sure, even on its face, such an argument seems problematic. One would have to accept, for example, that the drafters of a state constitution such as New Hampshire's-which denominated the governor the "Supreme Executive Magistrate" ${ }^{, 6}$ and declared that the legislative and executive branches "ought to be kept as separate from, and independent of, each other, as the nature of a free government will admit" ${ }^{\prime 69}$-nonetheless understood that they were violating the separation of powers principle by permitting legislative appointment of the state's "Secretary, Treasurer, and Commissary-General." ${ }^{70}$ The argument requires us to infer that the drafters of New Hampshire's constitution were self-consciously self-contradictory.

The project of unitary executive originalism is even more conspicuously doomed, however, by a closer investigation of the administrative tasks state legislatures assigned outside gubernatorial control and how state legislatures understood their discretion in providing for the appointment of public administrators. Such an investigation reveals that state legislatures frequently went beyond the express terms of state constitutions in assigning executive functions to persons outside executive control. To the extent state constitutions gave legislatures specific roles in the appointment of officials involved in public administration, legislatures did not regard these grants of authority to be narrow exceptions to a general principle of unitary executive control. They took them to be evidence of a different baseline principle, namely, legislative authority to design of the institutions of government and even to attenuate gubernatorial control over administration.

To evaluate fully the evidence in this respect, it is important to note that the early state constitutions-though they all permit legislatures to choose one or more significant state officers-treat the subject of appointments in rather different ways, as documented in the Appendix below. For example, the Georgia, Ohio, Tennessee, and Vermont constitutions all give their respective legislatures wide authority over the appointment of administrative officers. Georgia reserves to the legislature the selection of nearly all principal state officers, while giving that body the authority also to permit inferior officers to be chosen by "the governor, the courts of justice, or in such other manner as they may by law establish." ${ }^{, 71}$ The Ohio constitution allows generally for the appointment of civil officers not named in the constitution to "be made in such a manner as may be directed by law." Tennessee constitution vests appointment authority in the legislature for all

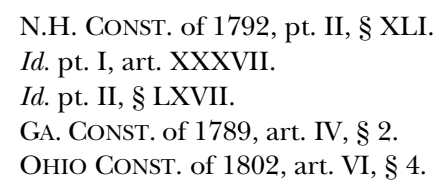


officers "not otherwise directed by [the] constitution." ${ }^{73}$ The Vermont constitution also implies legislative authority to provide by law, at its discretion, for the appointment of officers not otherwise covered by the constitution. $^{74}$

\begin{tabular}{|c|c|c|c|c|}
\hline & $\begin{array}{l}\text { Wide } \\
\text { Legislative } \\
\text { Authority } \\
\text { over the } \\
\text { Selection of } \\
\text { Adminis- } \\
\text { trative } \\
\text { Officers }\end{array}$ & $\begin{array}{l}\text { Legislative } \\
\text { Authority } \\
\text { over the } \\
\text { Selection of } \\
\text { Specific } \\
\text { Adminis- } \\
\text { trative } \\
\text { Officers }\end{array}$ & $\begin{array}{l}\text { Guberna- } \\
\text { torial } \\
\text { Authority } \\
\text { Over the } \\
\text { Selection of } \\
\text { Specific } \\
\text { Adminis- } \\
\text { trative } \\
\text { Officers }\end{array}$ & $\begin{array}{l}\text { Explicit } \\
\text { Residual } \\
\text { Appointment } \\
\text { Authority in } \\
\text { the Governor }\end{array}$ \\
\hline $\begin{array}{l}\text { Georgia } \\
\text { Ohio } \\
\text { Tennessee } \\
\text { Vermont } \\
\end{array}$ & $v$ & & & \\
\hline $\begin{array}{l}\text { Massachusetts* } \\
\text { New Hampshire* }\end{array}$ & & $\checkmark$ & $\checkmark$ & \\
\hline $\begin{array}{l}\text { Delaware } \\
\text { Kentucky } \\
\text { Maryland * } \\
\text { New York* } \\
\text { Pennsylvania } \\
\text { South Carolina }\end{array}$ & & $\checkmark$ & & $\checkmark$ \\
\hline $\begin{array}{l}\text { Connecticut } \\
\text { New Jersey } \\
\text { North Carolina } \\
\text { Virginia }\end{array}$ & & $v$ & & \\
\hline
\end{tabular}

* With the consent of a council.

By way of contrast, the Massachusetts and New Hampshire constitutions specify certain officers to be appointed by their respective legislatures and yet other specific officers to be chosen by a governor and council. ${ }^{75}$ Yet

73 TENN. CONST. of 1796 , art. VI, $\S 3$.

74 VT. CONST. of 1793, ch. II, § 11. It might be inferred that the North Carolina legislature had similarly broad authority to attenuate the governor's supervision of public administration; that constitution allowed the governor to "exercise all the other executive powers of government, limited and restrained as by this Constitution is mentioned, and according to the laws of the State." N.C. CONST. of 1776, art. XIX (emphasis added).

75 Mass. Const. of 1780 , Ch. 2, $\S 1$, Art. IX, and $\S 4$, Art. I; N.H. Const. of 1792, Part Second, §§ XLVI, XLVII. 
neither makes any express provision for civil officers other than those named in the constitution.

A third set of constitutions vests in state legislatures the appointment authority regarding specific state officers, while explicitly placing the residual appointment authority over all other offices in the governor. Examples include Delaware, Kentucky, Maryland (with consent of a council), New York (with consent of a council), Pennsylvania, and South Carolina. ${ }^{76}$ Yet a fourth group vests in state legislatures the appointment authority regarding specific state officers, but say nothing at all about the appointment of state civil officers not named in the constitution. These include Connecticut, New Jersey, North Carolina, and Virginia. The table above captures these groupings.

Legislative decisions in the first group of states to attenuate the governor's control over administration are less immediately on point for our inquiry because the constitutions in those states explicitly direct or at least permit the legislature to provide for administrative appointments outside the executive branch. In other words, except in an interesting way discussed below, the fact that legislatures in these states took administrative authority out of gubernatorial hands might not reveal much about those legislatures' understanding of separation of powers principles; they were mostly exercising powers that their constitutions explicitly conferred. But-and this is definitely instructive-state legislatures in the other groups went beyond the explicit grants of legislative appointments power that their constitutions authorized and provided by statute for what I have called nonconforming appointments, that is, appointments by authorities other than the governor of civil officers wielding what would seem today obviously to be executive power. Examples exist even in states whose constitutions gave governors broad residual authority to make appointments to officers not covered by the constitution.

For example, Massachusetts had one of the two constitutions that (1) specified certain officers to be appointed by its legislature and yet other specific officers by a governor and council, but (2) made no any express provision for civil officers other than those named in the constitution. In 1802, when the legislature wanted an authoritative determination of the boundary line between Massachusetts and Rhode Island, it appointed those commissioners by statute. ${ }^{77}$ The legislature did not treat gubernatorial appointment as an implicit mandatory default.

76 Del. COnST. of 1792, Art. II, § 8, Art. VIII, § 3, and Art. VIII, § 6; KY. ConsT. of 1792, Art. II, $\S 8$, and Art. VI, $\S 7$; MD. Const. of 1776, Arts. X, XIII, XLI, XLVIII; N.Y. ConST. of 1777, Arts. XXII and XXIII ; PA. CONST. of 1790, Art. II, § VIII, Art. V, § V; S.C. Const. of 1790 , Art. VI, $\$ \S 1$ and 2.

77 Act of Mar. 8, 1791, ch. 22, 1791 Mass. Acts 91. 
The Connecticut, New Jersey, North Carolina, and Virginia constitutions say nothing at all about the appointment of civil officers other than those named by the constitution. Yet the legislature of each enacted nonconforming appointments. For example, in 1784, Connecticut provided by statute for the appointment of state's attorneys by the county courts. ${ }^{78}$ This practice persisted until at least 1854, notwithstanding the adoption of the new Constitution in $1818 .^{79}$ As recounted earlier, the Connecticut Constitution of 1818 not only vested the executive power in the governor, but required the governor to take care that the laws be faithfully executed and gave the governor the equivalent of Opinions Clause authority. ${ }^{80}$ There was no provision in the 1818 article on the judiciary independently authorizing the judicial appointment of prosecutors.

Connecticut's practice of judicial appointments for prosecutors persisted in the face of a separation of powers system worded identically in relevant respects to the federal Constitution. A North Carolina statute of 1777 likewise empowered county courts to appoint additional prosecuting attorneys. ${ }^{81}$

New Jersey, for its part, authorized the licensing of taverns and inns by "the courts of general quarter sessions of the peace." "commissioners for laying out, opening and improving a road to accommodate travelers." ${ }^{83}$ Connecticut likewise provided for the licensing of taverns by county Courts of Common Pleas, ${ }^{84}$ and the Virginia legislature also appointed road commissioners. ${ }^{85}$ None of the legislatures in this group treated the specific provisions for non-conforming appointments in their constitutions to be exclusive, narrowly drawn exceptions from a legislative obligation to vest appointment authority in a governor.

Perhaps, however, most telling in this respect is the existence of nonconforming appointments even under state constitutions that appeared to

78 The First Laws of the State of Connecticut 10-11 (John D. Cushing ed., 1982).

79 A post-1854 statute appears to have reorganized the courts. Subsequent references to the judicial appointment of prosecuting attorneys place the power with "superior" courts. CONN. GEN. STAT. tit. 11, $\$ 35$ (1866). Connecticut retained some form of judicial involvement in the appointment of state's attorneys until 1985. See 1985 Conn. Acts 1379 $\S 142$ (repealing CONN. GEN. STAT ANN. tit. 51, § 51-278(a), and giving the power to appoint the chief state's attorney to the criminal justice commission's administrative head).

80 See supra note 65 and accompanying text.

811 The First LaWs of The State Of NORTh CARolina 311, § LXVIII (John D. Cushing ed., 1984).

82 Act of Feb. 24, 1797, ch. 438, 1796 N.J. Laws 180.

83 Act of Mar. 10, 1795, ch. 535, 1794 N.J. Laws 1022; see also Act of Feb. 15, 1794, ch. 462, 1793 N.J. Laws 891 (listing the appointments of multiple commissioners to lay out, open, and improve roads).

841792 Conn. Pub. Acts 437.

85 Act of Jan. 11, 1809, ch. 55, 1808 Va. Acts 61. 
give their governors significant residual appointment authority with regard to civil officers. Road commissioners were appointed directly by the legislatures of Delaware, ${ }^{86}$ Kentucky, ${ }^{87}$ Maryland, ${ }^{88}$ New York, ${ }^{89}$ and South Carolina. $^{90}$ In creating central banks for their respective states, the legislatures of South Carolina and Kentucky were all but indifferent to executive oversight of those institutions. The President and board of directors of the Bank of South Carolina were selected entirely by the legislature, and the Bank reported its account to the legislature. ${ }^{91}$ The enacting legislation placed a number of restrictions on the Bank's operation, but made no provision for their enforcement by the governor. There was even less direct state control over the Bank of Kentucky, half the directors of which were elected by private stockholders and half by the legislature. $^{92}$ The governor was permitted to inspect the Bank's books whenever he so requested, ${ }^{93}$ but had no other direct legal authority over the institution. In short, even under constitutions that envisioned broad appointing authority in the governor, legislatures still inferred they had the power to place certain administrative tasks in the hands of persons the governor did not appoint and control.

As I said earlier, it is not surprising to find non-conforming appointments in states like Georgia, Ohio, Tennessee, or Vermont, given that their constitutions envision broad legislative authority over appointments. But even they provide corroborating authority of a sort. Of the four, only Tennessee required the legislature to appoint all officers not otherwise provided for in the state constitution. ${ }^{94}$ Georgia, Ohio, and Vermont could have restricted non-conforming appointments-for example, grants of appointment authority to the courts- to strictly judicial officers. That would have shown a baseline commitment to an understanding of the separation of powers consistent in principle with unitary executive theory. But no such pattern exists. For example, notwithstanding Georgia's explicit constitutional commitment to the separation of powers, county judges were authorized to appoint local

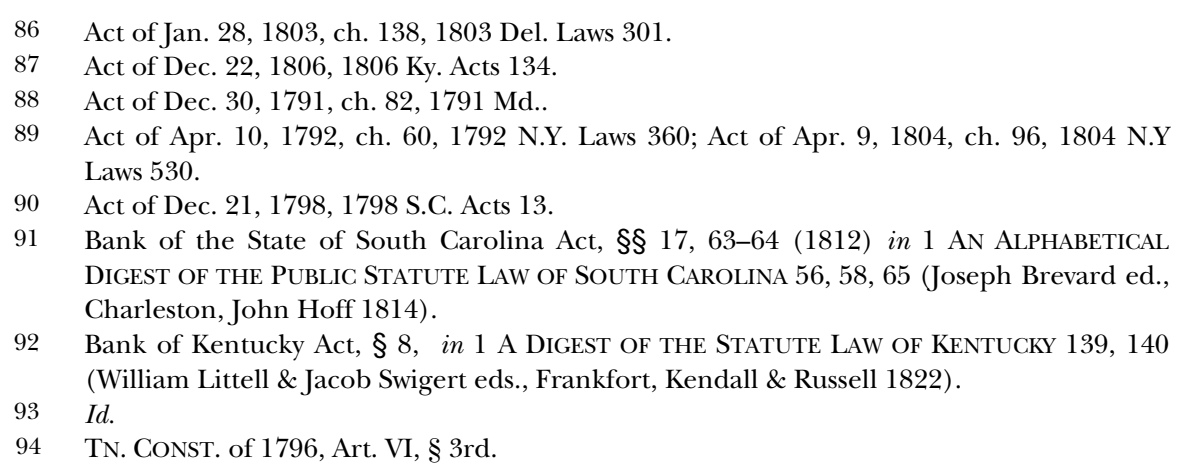


tobacco inspectors. ${ }^{95}$ When new roads were to be opened or altered, the relevant Georgia statute empowered the courts to appoint three-person inspection teams to examine the grounds urged to be cleared or altered and report to the court. ${ }^{96}$ The legislature also inferred it had authority to vest administrative tasks unrelated to the adjudication of cases in the courts, not the state executive branch. County courts had licensing and regulatory authority over taverns, ${ }^{97}$ clerks of county courts registered brands and marks; ${ }^{98}$ and county courts regulated roads (including the administration of applications to build new or amend existing roads). ${ }^{99}$ The Ohio legislature likewise assumed it could assign nonjudicial administrative functions to the courts, providing for the licensing by "the associate judges . . of the proper county" of ferries, taverns, and stores selling "any merchandise other than the growth or manufacture of the United States." 100

Like Georgia and Ohio, the Vermont legislature took advantage of its implicit authority to provide by statute for the non-gubernatorial appointment of officials, but did not limit those appointments to officials doing only non-executive tasks. For example, the legislature itself appointed members of several committees to "lay out ... public highway[s]." attorneys—one in each county—-were appointed by the legislature (and reappointed or replaced each legislative term). ${ }^{102}$ Not only did the state's attorneys prosecute "all matters and causes" on behalf of the state, but they

95 Act of Feb. 2, 1798, in A Digest OF THE LAWS OF THE STATE OF GEORGIA 683-84 (Robert Watkins \& George Watkins eds., Philadelphia, R. Aitken 1800) [hereinafter DigEST OF THE LAWS OF GEORGIA]. Lest it be objected that the statutory provisions in question were enacted prior to the 1798 Georgia constitution discussed in text, it should be recognized that the 1777 Georgia constitution likewise declared a separation of powers, GA. CONST. of 1777 , art. I, and the 1789 Constitution vested executive power in the governor, GA. CONST. of 1798 , art. II, $\S 1$.

96 Act of Dec. 20, 1792 in Digest OF THE LAwS OF GEORGIA, supra note 95, at 499. Georgia's system for road administration may not have been particularly effective, as the legislature repeatedly amended it. See, e.g., Act of Feb. 4, 1789 in Digest Of THE LaWs Of GEORGIA, supra note 95, at 386 (giving the superior courts full power and authority to order roads be built); Act of Dec. 19, 1818, 1818 Ga. Laws 401-02 (requiring justices of inferior courts to appoint three justices of the peace for erecting public roadways).

97 Act of Dec. 24, 1791 in DigEST OF THE LAws OF GEORGIA, supra note 95, at 453-54. This authority included fixing the price of liquor on a county-by-county basis.

98 Act of Dec. 8, 1792 in DigEST OF THE LAWS OF GEORGIA, supra note 95, at 456-57.

99 Act of Feb. 4, 1789 in Digest of THE LAws of GEORgIA, supra note 95, at 386; Act of Dec. 20, 1792 in DIGEST OF THE LAWS OF GEORGIA, supra note 95, at 499.

100 Act of Feb. 1, 1805, ch. 8, 1804 Ohio Laws 96, 99. The legislature later vested this authority in the "court of common pleas, of the proper county." Act of Feb. 8, 1810, ch. 34, § 1, 1809 Ohio Laws 107.

101 Act of Oct. 27, 1795, 1795 Vt. Acts \& Resolves 431.

102 Act of Nov. 10, 1797, ch. 83, § 1, 1797 Vt. Acts \& Resolves reprinted in THE LAWS OF THE State of Vermont of a Publick And Permanent Nature 556, 556 (Wm. Slade, Jr. ed., Windsor, Simeon Ide 1825). 
were also empowered to enforce monetary penalties issued by state courts. ${ }^{103}$ Although the state's attorneys were appointed by the legislature, they were in some measure supervised by the courts, which certified the statements of accounts that state's attorneys were required to submit to the treasurer, who in turn submitted them to the legislature. ${ }^{104}$

One reaction to this evidence is that I might simply have identified a host of specific administrative tasks-surveying, financial management, civil and criminal prosecution, tavern licensing, road administration, tobacco inspection, and so on-that were not uniformly understood in the late eighteenth century as inherently executive in a constitutional sense. But this reaction would not be a riposte; it would underscore my point. The original public meaning of executive power was either vague, ambiguous, or both. The vesting of executive power-even the vesting of executive power coupled with faithful execution obligations and the right to demand information from subordinates-did not imply in virtually any of the states a constitutional entitlement of governors to supervise a unitary executive branch.

Understandably, there was little early litigation over gubernatorial appointments and removals to shed further light on the states' firstgeneration understandings of their new constitutions. A rather striking example, however, comes from Pennsylvania, the constitution of which provided: "[The governor] shall appoint all officers whose offices are established by this Constitution, or shall be established by law, and whose appointments are not herein otherwise provided for...."105 An early Pennsylvania decision affirmed that the governor had the power to remove from office the inspector of salt provisions for the city of Philadelphia. ${ }^{106}$ The court reached its conclusion after interpreting Congress's Decision of 1789 as an endorsement of presidential removal power under Article II, which it took to apply at least as powerfully under the Pennsylvania constitution to imply a gubernatorial removal power. The court, however, explicitly recognized the legislature's power to limit removal by statute: "As to the tenure of ministerial offices in general, there can be no doubt but it is during pleasure, unless the law by which the office is established, order it otherwise."107 Moreover, a nearly contemporaneous decision of that state's

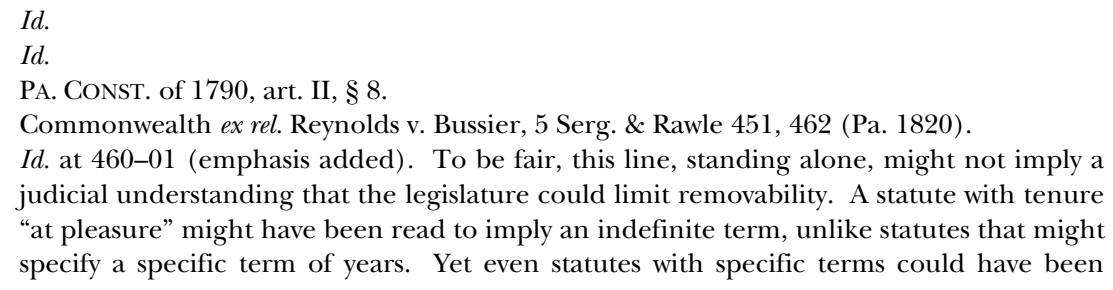


supreme court indicated that-notwithstanding the categorical language of the Pennsylvania constitution-the legislature could reserve the appointment of some administrative officials to itself or assign appointing authority to persons other than the governor. ${ }^{108}$

In thus going beyond the express terms of state constitutions that authorized non-conforming appointments explicitly, legislatures (and apparently at least one court) did not regard these grants of authority to be narrow exceptions to a general principle of unitary executive control. They regarded them as corroborating legislative powers to design the institutions of government and even to attenuate gubernatorial control over administration. "Executing the law" appears to have meant something like "executing the law to the extent and in the manner prescribed by the legislature." Insofar as the state constitutions shed light on the original public meaning of the language of Article II, they show that a proper construction of the relevant words did not connote a constitutional command for a unitary executive branch. ${ }^{109}$

\section{OLD ORIGINALISM: THE CASE OF THE NATIONAL BANK}

Prior to the advent of the "original public meaning" version of constitutional originalism, the theory of the hard unitary executive was typically advanced on original intent rather than semantic grounds. Indeed, the notion of "original public meaning" divorced from original intent has not gone unchallenged among originalists. ${ }^{110}$ Early federal administrative practice, however-the kinds of administrative practice I have explored in

understood at that time to leave the power of executive removal at will intact. I am grateful to Professor Prakash for pointing out the ambiguity.

108 Commonwealth ex rel. Lehman v. Sutherland, 3 Serg. \& Rawle 145, 149 (Pa. 1817) (" $[\mathrm{T}]$ here are matters of temporary and local concern, which, although comprehended in the term office, have not been thought to be embraced by the constitution. And when offices of that kind have been created, the legislature have sometimes made the appointment in the law which created them, sometimes given the appointment to others than the Governor, and sometimes given the power of removal to others, although the appointment was left to the Governor.").

109 I should also say that, in making this argument, I decided to forbear from relying on the many examples of state constitutions and statutes providing for the state legislative appointment of local administrative officers; such examples also betoken a fracturing of state administrative authority. I have not pursued the point only because the varying practices with regard to the appointment of local officials might be thought to reveal the different state and federal understandings of the vertical dimensions of public administration, rather than different understandings of the separation of powers per se.

110 See Richard S. Kay, Original Intention and Public Meaning in Constitutional Interpretation, 103 NW. U. L. Rev. 703, 704 (2009) ("[R] examin[ing] the shift from the subjective intent of the constitution-makers to the 'original public meaning' of the Constitution's words.”). 
Part III with regard to the states-has always been a problem for the unitarian version of original intent.

The interpretive touchstone for intention-based originalists would presumably be evidence of authorial expectation for the application of the founding text. There is inevitable ambiguity as to which authors count-the drafters or the ratifiers. But we can at least imagine the possibility that the drafters' text effectively communicated their intentions to the ratifiers or that, through speeches or supplementary texts, these intentions were conveyed accurately to voters whose affirmative ballots endorsed them. In any event, it is no surprise that, among intention-based originalists, the debates and output of the First Congress enjoy a special pride of place. ${ }^{111}$ Not only would that Congress be closest in time and thus most attuned to the contemporary meaning of the Philadelphia text, but many Members had actually helped draft the Constitution: eleven in the Senate (which comprised twenty-one to twenty-six Members, depending on vacancies and dates of election) and ten in the House, membership in which ranged from fifty-nine to sixty-five Members. ${ }^{112}$ Among the House Members was James Madison, who presumably would have been an authoritative source of intelligence about Framer intent. This is a group whose behavior might be thought an accurate mirror of Framer/ratifier intentions.

The problem for original intent unitarians is that the First Congress's handiwork regarding the structure of the initial administrative departments seems to belie the idea that the Framers intended a hard version of a unitary executive. ${ }^{113}$ For example, although the President was given significant flexibility and control when it came to the new Departments of War and of

111 See Myers v. United States, 272 U.S. 52, 136 (1926) ("We have devoted much space to this discussion and decision of the question of the presidential power of removal in the First Congress, not because a congressional conclusion on a constitutional issue is conclusive, but first because of our agreement with the reasons upon which it was avowedly based, second because this was the decision of the First Congress on a question of primary importance in the organization of the government made within two years after the Constitutional Convention and within a much shorter time after its ratification, and third because that Congress numbered among its leaders those who had been members of the convention. It must necessarily constitute a precedent upon which many future laws supplying the machinery of the new government would be based and, if erroneous, would be likely to evoke dissent and departure in future Congresses. It would come at once before the executive branch of the government for compliance and might well be brought before the judicial branch for a test of its validity.").

112 On the members of the First Congress, see 1st United States Congress, Wikipedia (visited Sept. 23, 2016), https://en.wikipedia.org/wiki/1st_United_States_Congress; Birth of the Nation: The First Federal Congress, 1789-1791: An Online Exhibit by the First Federal Congress Project, http://www.gwu.edu/ ffcp/exhibit/p1/members/.

113 See Jerry L. Mashaw, Creating the Administrative Constitution: The Lost One HUNDRED YeARS OF AMERICAN AdMinISTRATIVE LAW 293 (2012) (arguing that early notions of the unitary executive do not comport with twenty-first century proponents of unitary executive theory). 
Foreign Affairs (which shortly became the Department of State), this was not so regarding the Treasury. ${ }^{114}$ The Attorney General had no department at all and questionable authority over the part-time U.S. Attorneys, who were affiliated loosely with the Department of State and who supported themselves largely through the private practice of law. ${ }^{115}$ Again, to quote the work of Jerry Mashaw:

Congress created commissions and boards outside of any of the major departments to oversee the Mint, to buy back debt of the United States, and to rule on patent applications. Because these commissions and boards were made up of already existing officers of the United States, Congress in effect appointed the officers by the same legislative act that created their offices. From this perspective these were "independent commissions" in an even stronger sense than those we recognize today. Some of these ex-officio commissioners could be replaced by the President by replacing the officers. But other Boards of Commissioners contained non-removable officials like the Chief Justice and the President of the Senate. ${ }^{116}$

Congress's eclecticism in fashioning different administrative structures with different lines of accountability to different sources of supervision could hardly have been more conspicuous.

Another insufficiently-appreciated blow to the old originalist case for a hard unitary presidency is the First Bank of the United States. Separation of powers theorists have largely ignored the Bank, presumably because, as a kind of public-private partnership, it so obviously does not fit comfortably within any traditional view of the administrative state. Although she does not mention it specifically, the Bank seems to be an early example of the kind of "boundary" agency that Anne O'Connell shows has never been fully accounted for in administrative law scholarship. ${ }^{117}$

$114 \quad I d$. at 40.

115 Id. at 43; see also Jed Handelsman Shugerman, The Creation of the Department of Justice: Professionalization Without Civil Rights or Civil Service, 66 Stan. L. Rev. 121, 131 (2014) ("Until 1854, each Attorney General maintained a substantial private practice, and many did not even live in Washington, D.C. Until 1819, the Attorney General did not even have his own clerk, and until 1821, an office."). Professor Prakash has argued, however, that the records of early administrations show that Presidents Washington, Adams, and Jefferson all believed they were constitutionally entitled to direct the activities of district attorneys. Saikrishna Prakash, The Chief Prosecutor, 73 GEO. WASH. L. REv. 521, 553-63 (2005). Because Congress never purported to regulate presidential practices in this respect, this history does not substantiate that the Constitution guarantees the President a prosecution-directing role, only that-absent congressional limitation-Presidents thought they were not violating the law by ordering that prosecutions commence or desist, and none of the early Presidents' directives was sufficiently controversial on the merits to arouse resistance.

116 MASHAW, supra note 113, at 43-44.

117 Anne Joseph O'Connell, Bureaucracy at the Boundary, 162 U. PA. L. REV. 841, 914 (2014). 
Yet there is no doubt the Bank wielded government power. Professors Walter Dellinger and H. Jefferson Powell-at the time of their writing the Assistant Attorney General in charge of the Office of Legal Counsel ("OLC") and his former deputy, respectively—have observed that a modern-day OLC opinion on the constitutionality of a national bank would have focused immediately on possible separation of powers objections to the bill. ${ }^{118}$ The Bank may be inconvenient for originalist defenders of a unitary presidency, but it can hardly be ignored as irrelevant.

As Professor Mashaw recounts, the Bank of the United States-strongly urged by Framer Alexander Hamilton and modeled after the Bank of England ${ }^{119}$-effectively regulated the money supply. As Mashaw explains:

The statute authorizing the Bank provided a charter and specified the total capitalization of the enterprise. It also provided voting rules for stockholders, limits on total debt and the amount of interest to be charged, and a limit on the subscription to be made to the Bank by the federal government. But all of the Bank's operating policies-including when and where to establish branches-were left to the regulations to be adopted by the Bank's directors, only a minority of whom would be selected by the United States. 120

The precise degree of government influence in the selection of the directors of the First Bank of the United States is difficult to measure. Directors were to be chosen according to a plurality of shareholder votes, and the United States was limited to subscribing to no more than a fifth of the Bank's stock. ${ }^{121}$ Although the number of votes given to each shareholder depended on a complex formula, ${ }^{122}$ the United States bloc was presumably large enough to be influential, although the statute was silent as to who would vote on behalf of the United States. The government's minority status was cemented, however, when the Bank was re-chartered in 1816. Under the Second Bank Bill, the President was explicitly authorized to appoint five of the Bank's directors, with the Senate's advice and consent,

118 Walter Dellinger \& H. Jefferson Powell, The Constitutionality of the Bank Bill: The Attorney General's First Constitutional Law Opinions, 44 Duke L.J. 110, 131 (1994).

119 Alexander Hamilton, Dec. 13, 1790 Report on a National Bank, in 1 REPORTS OF THE SeCretary of the Treasury of the United States, PrePared in Obedience to the ACT OF THE 10TH MAY, 1800 75-76; see also JoHn THOM HoldsWORTH \& DAVIS R. DEWEY, THE First and Second Banks of the United States, S. Doc. No. 571, 61st Cong., 2d Sess. 19-22 (1910) (demonstrating Hamilton modeled the Bank of the United States after the Bank of England).

120 MASHAW, supra note 113 , at 47.

121 See Act of Feb. 25, 1791, ch. 10, §§ 4, 11, 1 Stat. 191, 192, 196 (providing for election of directors according to a plurality of voting shares and limiting the United States' subscription to no more than two million dollars out of the Bank's total ten million dollar capitalization).

122 See id. $\S 7,1$ Stat. 193 (expounding on the apportionment of shareholder votes throughout sixteen sub-parts). 
not even enough by themselves to constitute a quorum for doing business; private shareholders would choose the remaining twenty. ${ }^{123}$ Under both statutes, the Treasury Department enjoyed some limited supervisory authority over the Bank in the sense that the Secretary could demand reports and inspect Bank records. There was, however, no provision for presidential or Treasury authority to direct the bank in its operations. ${ }^{124}$

What makes this example of attenuated presidential influence so telling was that enactment of the Bank's charter in 1791 was very much the subject of constitutional debate. James Madison famously opposed the Bank as going beyond the enumerated powers of Congress, recalling that the Philadelphia Convention specifically declined to give Congress an express power of incorporation precisely to avoid the establishment of a national bank. ${ }^{125}$ The measure was debated vigorously in the House on constitutional grounds, even though unanimously approved by the Senate. ${ }^{126}$ Nor did Congress's adoption of the Bank bill end the intra-governmental deliberations. President Washington, who, of course, had presided over the Constitutional Convention, thought the issue of sufficient moment that, prior to signing the Bank's charter, he sought the formal opinions of his Attorney General and Secretaries of State and of the Treasury on the constitutional issue. ${ }^{127}$ We thus have four major statements by leading contemporary figures-Hamilton, Jefferson, Madison, and Edmund Randolph-all formally assessing the constitutionality of the bank bill.

Here's the rub: Not one of these opinions mentions the separation of powers as a source of objection or concern. Jefferson, Madison, and Randolph all thought the Bank unconstitutional as going beyond Congress's Article I powers, but none says a word about the lack of presidential supervisory authority or indeed anything about the Bank's attenuated accountability to even the Treasury Department. Hamilton does not acknowledge the Executive's attenuated influence over the Bank as

123 Act of April 10, 1816, ch. 44, $\S \S 8,11,3$ Stat. 266, 269-71 (providing for election of directors and establishing a quorum of seven).

124 MASHAW, supra note 113 , at 47.

125 James Madison, Feb. 2, 1791 Speech in Congress Opposing the National Bank, in JAMES MADISON: WRITINGS 1772-1836, at 480, 482 (1999).

126 Paul Brest et al., Processes of Constitutional Decisionmaking: Cases and MATERIALS 30 (6th ed. 2015).

127 Alexander Hamilton, Opinion on the Constitutionality of an Act to Establish a Bank, in 3 THE Works of AleXANder Hamilton 445 (Henry Cabot Lodge ed. 1904); Thomas Jefferson, Opinion on the Constitutionality of the Bill for Establishing a National Bank, in THE FEDERALIST: A COMMENTARY ON THE CONSTITUTION OF THE UNTIED STATES BY ALEXANDER HAMILTON, JAMES MADISON, AND JOHN JAY 651-52 (Paul Leicester Ford ed. 1898); Edmund Randolph, Feb. 12, 1791 The Constitutionality of the Bank Bill, in H. JEFFERSON POWELL, THE CONSTITUTION AND THE ATTORNEYS GENERAL 3 (1999). 
something that needs to be constitutionally explained away. He does not mention it at all.

Intent-oriented originalists might challenge the salience of this argument in two respects. The first is that the relevant actors in both Congress and the Executive might have failed to consider any separation of powers issue because they deemed the Bank a private and not a governmental entity, thus obviously beyond the President's reach. Perhaps it never occurred to the First Congress that the Bank's directors and officers might be thought Officers of the United States, subject by constitutional command to presidential appointment, removal, and direction. To the extent this speculation is accurate, however, it would only make the originalist position weaker. It would imply that those most familiar with the Constitution's drafting and the ratification debates were unaware of any authorial intent to confine the delegation of significant government authorities even to purely government institutions. If that's so-and I think it is-then it must follow that there was no authorial intent to confine the delegation of discretionary government authority exclusively to officials whom the President could command and remove.

A second speculative riposte might be that separation of powers issues were not raised because of the philosophical alignment of the principal antagonists. As Mashaw points out: "Federalists ... emphasized executive leadership in ways that sometimes led their political opponents to brand them monarchists." ${ }^{128}$ The Virginians-Jefferson, Madison, and Randolphcould conceivably have been reluctant to criticize the Bank for being under insufficient presidential control because such control might have been as problematic to the nascent Jeffersonian caucus in Congress as was Congress's extension of its implied legislative powers. ${ }^{129}$ Any "correction" for the former problem would have rendered the Bank even less attractive in their eyes. As for Hamilton and Washington, perhaps they noticed the issue but were reluctant to mention it because, as nationalists above all, they thought the Bank too important to cavil over matters of executive control. (I suspect this latter scenario is deeply counterfactual, given that Hamilton's

128 Mashaw, supra note 3 , at $671-72$.

129 This is not to say that this trio championed a weak presidency. Whether President Jefferson's own ambitious uses of executive power represented a change from his earlier views of the presidency is the subject of debate. See Jeremy D. Bailey, The Republican Executive: Thomas Jefferson and the Development of Presidential Power, in EXTRAORDINARY TIMES 1-4 (Stephen Dawson et al., eds. 2001) (supporting the proposition that Jefferson desired the presidency be characterized by an energetic executive); John Yoo, Jefferson and Executive Power, 88 B.U. L. REv. 421, 421-25 (2008) (advocating the idea that President Jefferson's actions as President show that he was in favor of a strong presidency within the limited framework of the federal government). On President Jefferson's and President Madison's views of Article II, see Calabresi \& Yoo, supra note 1, at 64-82. 
design for the Bank was always for a private institution; it is doubtful he thought he was compromising any constitutional principle.) In any event, since the Bank's opponents raised no separation of powers arguments, its supporters might also have felt no compulsion to raise any.

In this respect, however, it is enlightening to look at the Bank debate at a later stage in history. As is well known, Congress failed to re-charter the Bank when the first charter lapsed in 1811, leaving the U.S. to fight the War of 1812 without the aid of a central fiscal institution. The resulting fiscal difficulties ${ }^{130}$ prompted Congress in 1816 to charter a Second Bank of the United States for another twenty years, again much to the chagrin of the agricultural states. Congressional Whigs voted in 1832 to extend the charter four years early thinking the move would help them in the 1832 election. ${ }^{131}$ Instead, Andrew Jackson made his vehement opposition to the Bank a central campaign issue and sent Congress a vigorous and detailed veto message. $^{132}$

Key portions of Jackson's message, reminiscent of earlier statements in opposition to the Bank, again challenged the Bank as unconstitutional. While taking note that the Supreme Court had approved Congress's exertion of an implicit incorporation power, Jackson took the position that the Supreme Court had been appropriately deferential to the elected branches in applying the Necessary and Proper Clause, but that he, as President, need not be. ${ }^{133}$

130 The First National Bank would have been insufficiently capitalized to lend the government enough money to finance a war, and reliance on the First National Bank was not the Monroe Administration's plan. Its hope lay instead with the chartering of a Second National Bank with much greater capital. The failure to recharter the Bank also meant there were no national banks to convert bank notes into specie, resulting in a proliferation of state currencies and the necessity for the Treasury Department to accept private banknotes in payment of taxes-a process that required Treasury to have to negotiate continually over the terms of exchange. See MAX M. EdLING, A Hercules IN THE CRADLE: WAR, MONEY, AND THE AMERICAN STATE, 1783-1867, at 122-23 (2014).

131 BREST ET AL., supra note 126, at 77.

132 Veto Message from President Jackson Regarding the Bank of the United States (July 10, 1832), reprinted in JAMES D. RICHARDSON, ED., A COMPILATION OF THE MESSAGES AND PAPERS OF THE PRESIDENTS 1139-1154 (1897).

133 Id. at 1146 ("The principle [the Court] affirmed is that the 'degree of its necessity,' involving all the details of a banking institution, is a question exclusively for legislative consideration. A bank is constitutional, but it is the province of the Legislature to determine whether this or that particular power, privilege, or exemption is 'necessary and proper' to enable the bank to discharge its duties to the Government, and from their decision there is no appeal to the courts of justice. Under the decision of the Supreme Court, therefore, it is the exclusive province of Congress and the President to decide whether the particular features of this act are necessary and proper in order to enable the bank to perform conveniently and efficiently the public duties assigned to it as a fiscal agent, and therefore constitutional, or unnecessary and improper, and therefore unconstitutional.") 
Jackson did not doubt that the Bank was established to be an agency of government. And, unlike his anti-Federalist forebears, he was no critic of a strong presidency. On the contrary, modern advocates of a hard unitary executive cite the Jackson Administration as a source of significant precedents in support. ${ }^{134}$ Jackson was thus intellectually and politically well positioned to voice any available separation of powers attack on the Bank. But Jackson-who had every reason to attack the Bank on any plausible constitutional basis and who was, at that stage in history, our most proexecutive Chief Executive, did not object to the Bank on any separation of powers ground. In a veto message exceeding 8000 words, the Bank's relationship to the Executive is mentioned only once:

The bank is professedly established as an agent of the executive branch of the Government, and its constitutionality is maintained on that ground. Neither upon the propriety of present action nor upon the provisions of this act was the Executive consulted. It has had no opportunity to say that it neither needs nor wants an agent clothed with such powers and favored by such exemptions. There is nothing in its legitimate functions which makes it necessary or proper. Whatever interest or influence, whether public or private, has given birth to this act, it can not be found either in the wishes or necessities of the executive department, by which present action is deemed premature, and the powers conferred upon its agent not only unnecessary, but dangerous to the Government and country.

In other words, Jackson's objections to the Bank on behalf of the executive branch had nothing to do with his non-supervision of the Bank, but rather to the reenactment of its charter under the Necessary and Proper Clause without taking account of Jackson's view that the Bank did not meet appropriate tests of necessity and propriety. Had strong grounds emerged between 1789 and 1832 to support a view of founding intent as mandating the hard version of the unitary presidency, no one would have been likelier to say so than Andrew Jackson. He did not. This is a revealing dog that did not bark.

The National Bank example hardly exhausts the case against an intentbased originalist argument for a hard unitary executive. It dramatically illustrates, however, "the limitations of...historical claims that the relationship of administrations to the political and legal branches of government was well-established early in the nation's history." ${ }^{136}$ As research into both state and federal practice shows, public administration was

134 Calabresi \& Yoo, supra note 1, at 95-104.

135 Veto Message from President Jackson, supra note 132, at 1152-53. It is worth noting that my argument holds whether or not Jackson accurately understood the Bank to be a government institution. My point is that he thought it was and yet failed to object to it on separation of powers grounds.

136 Mashaw, supra note 113, at 11. 
frequently organized in ways that are inconsistent with the hard unitary executive paradigm. Originalist defenders of a hard unitary executive are thus left with arguing that the exceptions are inapposite, that the founding generation did not actually understand its constitutional documents, or that the texts of the documents were just lip service to principles that legislatures governed by the late eighteenth century constitutions simply violated with regularity. There is, of course, a simpler explanation-that the documents were all but universally understood as giving legislatures substantial freedom to organize public administration, including decisions to limit direct chief executive control over administrative outcomes. Understood in this way, history confirms Professor Mashaw's conclusion: "The notion that we have fallen in the modern era from some prior state of separation-of-powers grace . . is simply a mistake." ${ }^{, 137}$

\section{CONCLUSION}

The supposed appeal of original public meaning originalism is largely two-fold. With respect to methodology, it purports to avoid the attribution of intent problems often cited with respect to old-style originalism. On a normative level, if the relevant text had a conventional, stable meaning at the time of its use, then shared knowledge of that meaning would cause those drafting the Constitution and those voting for and against it to possess a common understanding of what they were collectively producing. It is this imagined consensus that gives weight to the claim that modern readers of the Constitution should treat the text as significantly constraining. With regard to the vesting of executive power, original public meaning originalism substantiates, at least as clearly as old-style original intent-based originalism, that the founding generation did not have any "fixed general idea about the relationship of the President [or a governor] to administration., ${ }^{138}$

Skeptical readers may still think this argument gives too little weight to the syllogism noted above. Does not the vesting of "the" executive power in "a" President demand that executive power be treated as a single, indivisible thing that may be assigned to no official other than the President? Given Article I, it plainly does not. That is, the Constitution, as Professor Prakash himself recognizes, "grants some eighteenth century executive powers-such as the powers over war and foreign commerce-to Congress." ${ }^{\text {"139 }}$ At the very least, this implies that the Executive Power Vesting Clause needs to be read as follows: "Except as otherwise provided in this Constitution, the executive

$I d$. at 25 .

Mashaw, supra note 3, at 668 .

Prakash, THE CONSTITUTION OF THE ORIGINAL EXECUTIVE, supra note 5, at 83. 
power shall be vested in a President of the United States of America." The implicit Exceptions Clause might itself be regarded as a repudiation of the hard version of unitary executive theory.

But even considered linguistically, the weight that unitarians attach to "the" and "a" is simply too great. To see this, imagine that Article II opened as follows: "Executive power shall be vested in a President of the United States of America." The absence of any modifier preceding "[e]xecutive power" could have easily signaled that executive power might also be vested elsewhere-perhaps in the "officers" and "executive departments" mentioned elsewhere in Article II-so long as those specific executive powers constitutionally lodged with the President remained intact. If I am right about this, then the notion of an indivisible executive power rests entirely with the word, "the."

Yet even a moment's reflection reminds us that "the" is often used in a manner that does not suggest singularity or exclusivity. Imagine that the Constitution provided: "The dessert shall be the tastiest part of the President's dinner." This would mean exactly the same as: "Dessert shall be the tastiest part of the President's dinner." The use of the word "the" is compatible with the notion of a dessert that is not a singular presidential entitlement. Others may have dessert, too. Thus, unlike Article III, which conveys to the courts not just "the judicial power," but "the judicial power of the United States"-a rather clear signal of comprehensiveness-Article II can be read to permit the legislative allocation of executive power to members of the executive branch other than the President. Even as to those officers, of course, the President must "take care that the laws be faithfully executed." But the President need not have power to execute the laws personally. The President need not enjoy removal power at will in the face of contrary statutes. The President need not have the authority to demand, without firing an official, that the official exercise his or her discretionary authority in the manner the President prefers.

This does not necessarily mean that a hard unitary executive reading of the Constitution is unjustified; it simply cannot be justified adequately through any narrowly formalist version of originalism. Whether the Constitution commands a hard version of the unitary executive should be understood as a question of nonoriginalist, albeit historically informed constitutional construction. That construction, in turn, should be a pragmatic one, taking due cognizance of a variety of considerations. These would include the general values that animated the 1787 Constitution, our now-more-than-two centuries of institutional practice, and what we have learned and are still learning about the relationship of different institutional arrangements to different kinds of institutional outcomes. Debates about these factors are no more likely to yield broad consensus conclusions than are debates over the meaning of historical texts. But that uncertainty is itself 
an argument for constitutional fluidity—for giving our political institutions more, rather than less power to structure and restructure their interrelationship. Absent compelling evidence, courts and originalist scholars should be reluctant to bind the elected branches to any one highly debatable view of the constitutional organization chart. Nothing in the original public meaning of Article II requires us to do so. 


\section{APPENDIX: STATE LEVEL ADMINISTRATIVE OFFICIALS IN EARLY STATE CONSTITUTIONS}

\begin{tabular}{|c|c|}
\hline $\begin{array}{l}\text { Connecticut } \\
1818\end{array}$ & $\begin{array}{l}\text { Article Fourth. Of the Executive Department. } \\
\S 19 \text {. A Controller of the public accounts shall be } \\
\text { annually appointed by the General Assembly. }\end{array}$ \\
\hline $\begin{array}{l}\text { Delaware } \\
1792\end{array}$ & $\begin{array}{l}\text { Art. II, } \S 8 \text {. [The governor] shall appoint all officers } \\
\text { whose offices are established by this constitution, or } \\
\text { shall be established by law, and whose appointments } \\
\text { are not herein otherwise provided for... } \\
\text { Art. VIII, } \S 3 \text {. The State treasurer shall be appointed } \\
\text { annually by the house of representatives, with the } \\
\text { concurrence of the Senate. } \\
\text { Art. VIII, } \S 6 \text {. Attorneys at law, all inferior officers in the } \\
\text { treasury department, election officers, officers relating } \\
\text { to taxes, to the poor, and to highways, constables and } \\
\text { hundred officers, shall be appointed in such manner as } \\
\text { is or may be directed by law. }\end{array}$ \\
\hline $\begin{array}{l}\text { Georgia } \\
1789\end{array}$ & $\begin{array}{l}\text { Art. IV, } \S 2 \text {. All elections shall be by ballot, and the } \\
\text { house of representatives, in all appointments of State } \\
\text { officers, shall vote for three persons; and a list of the } \\
\text { three persons having the highest number of votes shall } \\
\text { be signed by the speaker, and sent to the Senate, which } \\
\text { shall from such list determine, by a majority of their } \\
\text { votes, the officer elected, except militia officers and the } \\
\text { secretaries of the governor, who shall be appointed by } \\
\text { the governor alone, under such regulations and } \\
\text { restrictions as the General Assembly may prescribe. The } \\
\text { General Assembly may vest the appointment of inferior } \\
\text { officers in the governor, the courts of justice, or in such } \\
\text { other manner as they may by law establish. }\end{array}$ \\
\hline $\begin{array}{l}\text { Kentucky } \\
1792\end{array}$ & $\begin{array}{l}\text { Art. II, } \S 8 \text {. [The governor] shall nominate, and by and } \\
\text { with the advice and consent of the Senate, appoint all } \\
\text { officers, whose offices are established by this } \\
\text { Constitution, or shall be established by law, and whose } \\
\text { appointments are not herein otherwise provided for... } \\
\text { Art. VI, } \S 7 \text {. The State Treasurer shall be appointed } \\
\text { annually by the joint ballot of both Houses. }\end{array}$ \\
\hline
\end{tabular}




\begin{tabular}{|c|c|}
\hline $\begin{array}{l}\text { Maryland } \\
1776\end{array}$ & $\begin{array}{l}\text { Art. X. [The House of Delegates] may examine and } \\
\text { pass all accounts of the State, relating either to the } \\
\text { collection or expenditure of the revenue, or appoint } \\
\text { auditors, to state and adjust the same. } \\
\text { Art. XIII. That the Treasurers (one for the western, and } \\
\text { another for the eastern shore) and the Commissioners } \\
\text { of the Loan Office, may be appointed by the House of } \\
\text { Delegates, during their pleasure... } \\
\text { Art. XLI. That there be a Register of Wills appointed } \\
\text { for each county who shall be commissioned by the } \\
\text { Governor, on the joint recommendation of the Senate } \\
\text { and House of Delegates ... } \\
\text { Art. XLVIII. That the Governor, for the time being, } \\
\text { with the advice and consent of the Council, may } \\
\text { appoint the Chancellor, and all Judges and Justices, the } \\
\text { Attorney-General, Naval Officers, officers in the regular } \\
\text { land and sea service, officers of the militia, Registers of } \\
\text { the Land Office, Surveyors, and all other civil officers of } \\
\text { government (Assessors, Constables, and Overseers of } \\
\text { the roads only excepted) and may also suspend or } \\
\text { remove any civil officer who has not a commission, } \\
\text { during good behaviour; and may suspend any militia } \\
\text { officer, for one month: and may also suspend or } \\
\text { remove any regular officer in the land or sea service: } \\
\text { and the Governor may remove or suspend any militia } \\
\text { officer, in pursuance of the judgment of a Court } \\
\text { Martial. }\end{array}$ \\
\hline $\begin{array}{l}\text { Massachusetts } \\
1780\end{array}$ & $\begin{array}{l}\text { Chapter } 2, \S 1 \text {, Art. IX. All judicial officers, the } \\
\text { attorney-general, the solicitor-general, all sheriffs, } \\
\text { coroners, and registers of probate, shall be nominated } \\
\text { and appointed by the governor, by and with the advice } \\
\text { and consent of the council; and every such nomination } \\
\text { shall be made by the governor, and made at least seven } \\
\text { days prior to such appointment. } \\
\text { Chapter 2, } \S 4 \text {, Art. I. The secretary, treasurer, and } \\
\text { receiver-general, and the commissary-general, notaries } \\
\text { public, and naval officers, shall be chosen annually, by } \\
\text { joint ballot of the senators and representatives, in one } \\
\text { room. }\end{array}$ \\
\hline
\end{tabular}




\begin{tabular}{|c|c|}
\hline $\begin{array}{l}\text { New Hampshire } \\
1792\end{array}$ & $\begin{array}{l}\text { Part Second, FORM OF GOVERNMENT, } \S \text { V: And } \\
\text { farther, full power and authority are hereby given and } \\
\text { granted to the said general court... to name and settle } \\
\text { annually, or provide by fixed laws for the naming and } \\
\text { settling, of all civil officers within this State; such } \\
\text { officers excepted the election and appointment of } \\
\text { whom are hereafter in this form of government } \\
\text { otherwise provided for; and to set forth the several } \\
\text { duties, powers, and limits of the several civil and } \\
\text { military officers of this State. } \\
\S \text { XLVI. All judicial officers, the attorney-general, } \\
\text { solicitors, all sheriffs, coroners, registers of probate, and } \\
\text { all officers of the navy, and general and field officers of } \\
\text { the militia shall be nominated and appointed by the } \\
\text { governor and council; and every such nomination shall } \\
\text { be made at least three days prior to such appointment; } \\
\text { and no appointment shall take place unless a majority } \\
\text { of the council agree thereto. } \\
\S \text { XLVII. The governor and council shall have a } \\
\text { negative on each other, both in the nominations and } \\
\text { appointments. Every nomination and appointment } \\
\text { shall be signed by the governor and council, and every } \\
\text { negative shall be also signed by the governor or council } \\
\text { who made the same. } \\
\S \text { LXVII. The secretary, treasurer, and commissary- } \\
\text { general shall be chosen by joint ballot of the senators } \\
\text { and representatives, assembled in one room. }\end{array}$ \\
\hline $\begin{array}{l}\text { New Jersey } \\
1776\end{array}$ & $\begin{array}{l}\text { Art. XII. [T] he Attorney-General, and Provincial } \\
\text { Secretary, shall continue in office for five years: and the } \\
\text { Provincial Treasurer shall continue in office for one } \\
\text { year; and that they shall be severally appointed by the } \\
\text { Council and Assembly.... }\end{array}$ \\
\hline
\end{tabular}




\begin{tabular}{|c|c|}
\hline $\begin{array}{l}\text { New York } \\
1777\end{array}$ & $\begin{array}{l}\text { Art. XXII. And this convention doth further, in the } \\
\text { name and by the authority of the good people of this } \\
\text { State, ordain, determine, and declare, that the } \\
\text { treasurer of this State shall be appointed by act of the } \\
\text { legislature, to originate with the assembly: Provided, } \\
\text { that he shall not be elected out of either branch of the } \\
\text { legislature. } \\
\text { Art. XXIII. That all officers, other than those who, by } \\
\text { this constitution, are directed to be otherwise } \\
\text { appointed, shall be appointed in the manner following, } \\
\text { to wit: The assembly shall, once in every year, openly } \\
\text { nominate and appoint one of the senators from each } \\
\text { great district, which senators shall form a council for } \\
\text { the appointment of the said officers, of which the } \\
\text { governor for the time being, or the lieutenant } \\
\text { governor, or the President of the senate, when they } \\
\text { shall respectively administer the government, shall be } \\
\text { President and have a casting voice, but no other vote; } \\
\text { and with the advice and consent of the said council, } \\
\text { shall appoint all the said officers; and that a majority of } \\
\text { the said council be a quorum. }\end{array}$ \\
\hline $\begin{array}{l}\text { North Carolina } \\
1776\end{array}$ & $\begin{array}{l}\text { Art. XIII. That the General Assembly shall, by joint } \\
\text { ballot of both houses, appoint } / \ldots \text {. [the] Attorney- } \\
\text { General, who shall be commissioned by the Governor, } \\
\text { and hold ... office[] during good behavior. } \\
\text { Art. XXII. That the General Assembly shall, by joint } \\
\text { ballot of both Houses, annually appoint a Treasurer or } \\
\text { Treasurers for this State. } \\
\text { Art. XXIV. That the General Assembly shall, by joint } \\
\text { ballot of both Houses, triennially appoint a Secretary } \\
\text { for this State. }\end{array}$ \\
\hline $\begin{array}{l}\text { Ohio } \\
1802\end{array}$ & $\begin{array}{l}\text { Art. II, } \S 16-\text { A secretary of State shall be appointed by } \\
\text { a joint ballot of the Senate and House of } \\
\text { Representatives ... } \\
\text { Art. VI, } \S 2-\text { The State Treasurer and Auditor shall be } \\
\text { triennially appointed by a joint ballot of both Houses of } \\
\text { the Legislature. } \\
\text { Art. VI, } \$ 4-\text { The appointments of all civil officers, not } \\
\text { otherwise directed by this constitution, shall be made in } \\
\text { such manner as may be directed by law. }\end{array}$ \\
\hline
\end{tabular}




\begin{tabular}{|c|c|}
\hline $\begin{array}{l}\text { Pennsylvania } \\
1790\end{array}$ & $\begin{array}{l}\text { Art. II, Sect. VIII. [The governor] shall appoint all } \\
\text { officers, whose offices are established by this } \\
\text { Constitution, or shall be established by law, and whose } \\
\text { appointments are not herein otherwise provided for .. } \\
\text { Art. V, Sect. V. The State Treasurer shall be appointed, } \\
\text { annually, by the joint vote of the members of both } \\
\text { Houses. All other officers in the treasury department, } \\
\text { attornies at law, election officers, officers relating to } \\
\text { taxes, to the poor and highways, constables, and other } \\
\text { township officers, shall be appointed in such manner as } \\
\text { is or shall be directed by law. }\end{array}$ \\
\hline $\begin{array}{l}\text { South Carolina } \\
1790\end{array}$ & $\begin{array}{l}\text { Art. VI, } \S 1 \text {. The ... commissioners of the treasury, } \\
\text { secretary of the State, and surveyor-general shall be } \\
\text { elected by the joint ballot of both houses in the house } \\
\text { of representatives.... } \\
\text { Art. VI, } \S 2 \text {. All other officers shall be appointed as they } \\
\text { hitherto have been, until otherwise directed by law ... } \\
.140\end{array}$ \\
\hline $\begin{array}{l}\text { Tennessee } \\
1796\end{array}$ & $\begin{array}{l}\text { Art. V, } \S 2 \text { nd. The general assembly shall, by joint ballot } \\
\text { of both houses, appoint } \ldots \text { an attorney or attorneys for } \\
\text { the State, who shall hold their respective offices during } \\
\text { good behavior. } \\
\text { Art. VI, } \S 3 \text { rd. The appointment of all officers, not } \\
\text { otherwise directed by this Constitution, shall be vested } \\
\text { in the legislature. }\end{array}$ \\
\hline
\end{tabular}

${ }_{140}$ This section would appear to carry forward the relevant portions of the South Carolina Constitution of 1778 , which provided as follows:

XXIX. That two commissioners of the treasury, the secretary of the State, the register of mesne conveyances in each district, attorney-general, surveyor-general, powder-receiver, collectors and comptrollers of the customs and waiters, be chosen . . . by the senate and house of representatives jointly, by ballot, in the house of representatives...

XXXII. That the governor and commander-in-chief, with the advice and consent of the privy council, may appoint during pleasure, until otherwise directed by law, all other necessary officers, except such as are now by law directed to be otherwise chosen. 


\begin{tabular}{|c|c|}
\hline $\begin{array}{l}\text { Vermont } \\
1793\end{array}$ & $\begin{array}{l}\text { Chap. II, } \$ 10 \text {. The Supreme Executive Council of this } \\
\text { State, shall consist of a } \\
\text { Governor, Lieutenant Governor, and twelve persons, } \\
\text { chosen in the following manner, viz. The freemen of } \\
\text { each town shall, on the day of election for choosing } \\
\text { Representatives to attend the General Assembly, bring } \\
\text { in their votes for Governor, with his name fairly } \\
\text { written, to the Constable, who shall seal them up, and } \\
\text { write on them, Votes for the Governor, and deliver } \\
\text { them to the Representative chosen to attend the } \\
\text { General Assembly; and at the opening of the General } \\
\text { Assembly, there shall be a committee appointed out of } \\
\text { the Council and Assembly, who, after being duly sworn } \\
\text { to the faithful discharge of their trust, shall proceed to } \\
\text { receive, sort, and count the votes for the Governor, and } \\
\text { declare the person who has the major part of the votes, } \\
\text { to be Governor for the year ensuing. And if there be } \\
\text { no choice made, then the Council and General } \\
\text { Assembly, by their joint ballot, shall make choice of a } \\
\text { Governor. The Lieutenant Governor and Treasurer } \\
\text { shall be chosen in the manner above directed. And } \\
\text { each freeman shall give in twelve votes for twelve } \\
\text { Councillors, in the same manner, and the twelve } \\
\text { highest in nomination shall serve for the ensuing year } \\
\text { as Councillors. } \\
\text { Chap. II, } \S 11 \text {. The Governor, and in his absence the } \\
\text { Lieutenant Governor, with the } \\
\text { Council, (a major part of whom, including the } \\
\text { Governor or Lieutenant Governor, shall be a quorum } \\
\text { to transact business) shall have power to commission } \\
\text { all Officers-and also to appoint Officers, except } \\
\text { where provision is, or shall be otherwise made, by law, } \\
\text { or this Frame of Government... }\end{array}$ \\
\hline $\begin{array}{l}\text { Virginia } \\
1776\end{array}$ & $\begin{array}{l}\text { Unnumbered para. 35. The two Houses of Assembly } \\
\text { shall, by joint ballot, appoint ... [the] Secretary, and } \\
\text { the Attorney-General, to be commissioned by the } \\
\text { Governor, and continue in office during good } \\
\text { behaviour. } \\
\text { Unnumbered para. 40. A Treasurer shall be appointed } \\
\text { annually, by joint ballot of both Houses. }\end{array}$ \\
\hline
\end{tabular}

